\title{
الحذف في شعرِ ابن فُرْكون الغرناطي
}

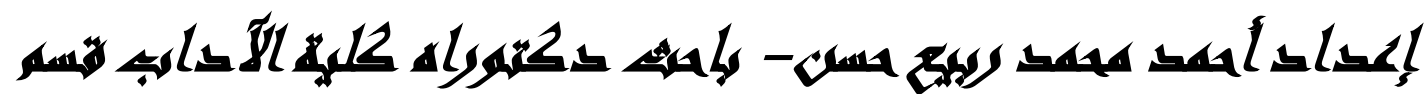

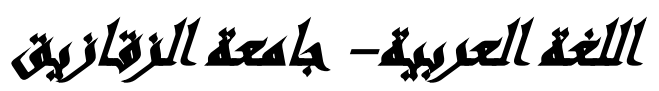

\section{كلديمها.}

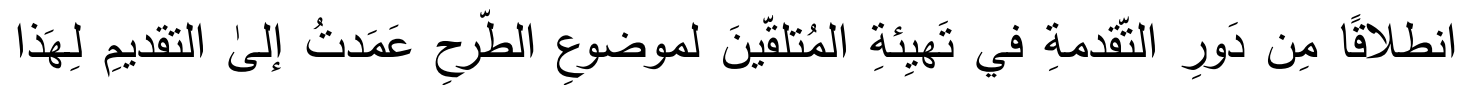

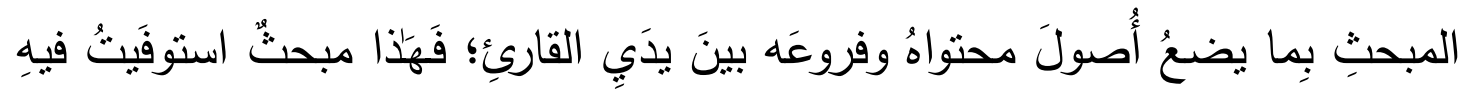

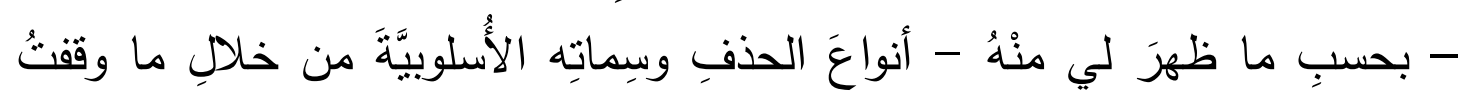

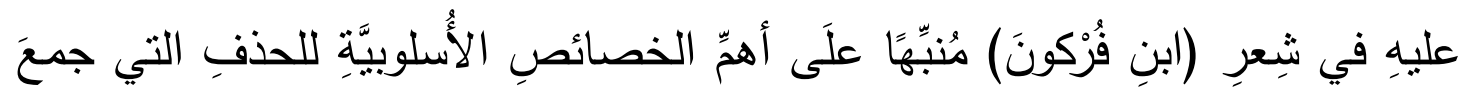

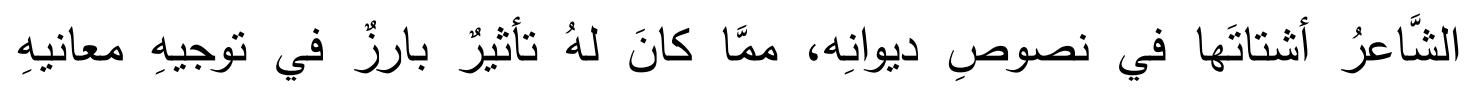

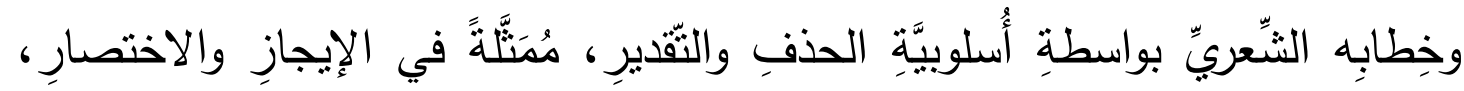

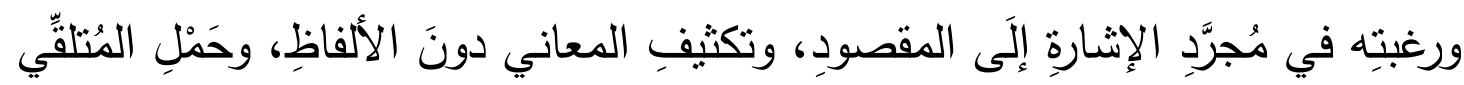

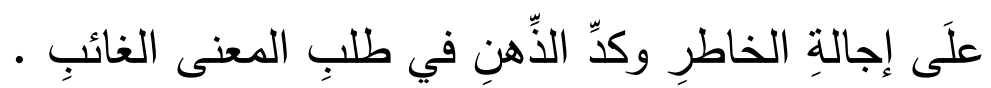
وقد كانَ مِن دواعي اختياري لموضوعِ الحذفِ عندَ (ابنِ فُركون) ما للحذفِ من عظيِِ

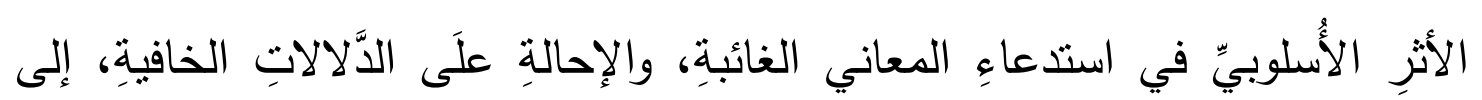
جانبِ ما وققتُ من تللكَ الأنواع التي اصطفاها (ابنُ فُرْكونَ)؛ لِيُعبِّرَ بها عن مقاصدِه

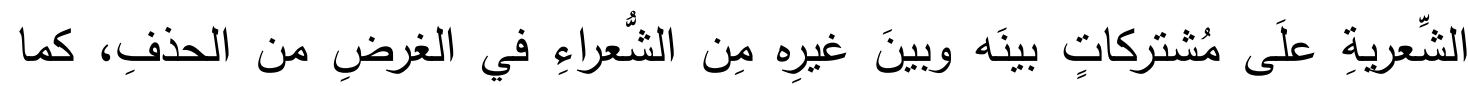

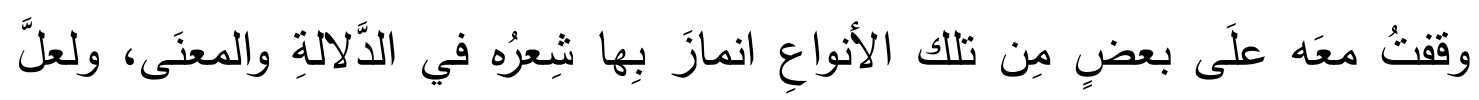
النَّاظرَ في ديوانِه يلحظُ بعينِ المُستبصرِ بقواعدِ الأُسلوبيَّةِ أنَّ (ابنَ فُركونَ) انفردَ

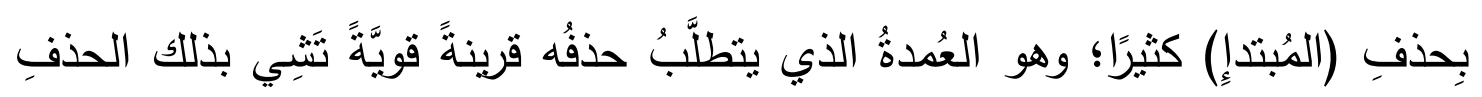

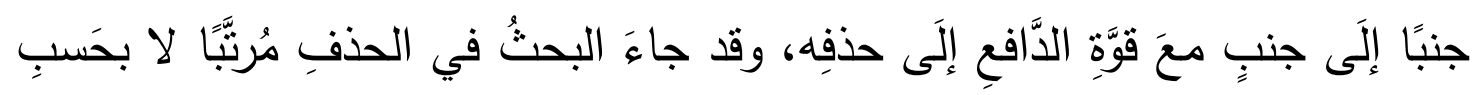
الإيرادِ في الدِّوانِ، بل وفقًا للنّسبِ المئويَّةِ التي استحوزَ عليها كلُّ نوعِ مِن أنواعِ 


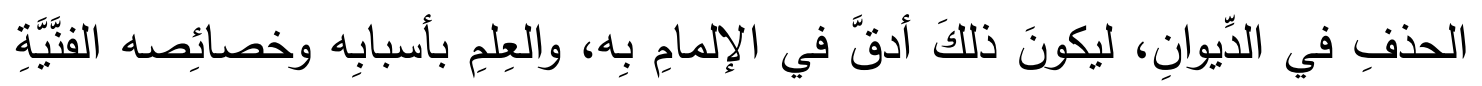

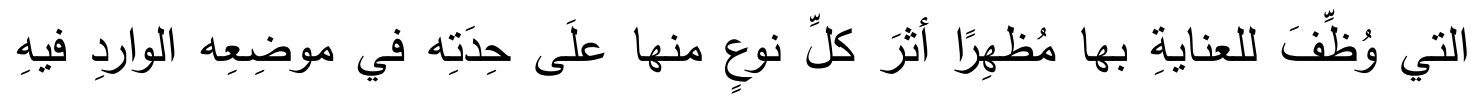

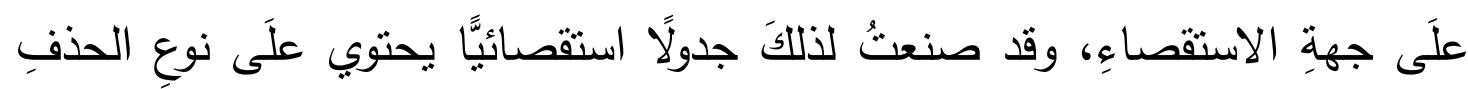

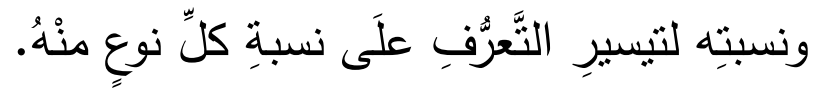

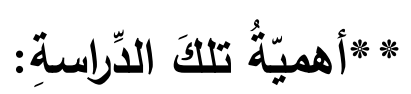

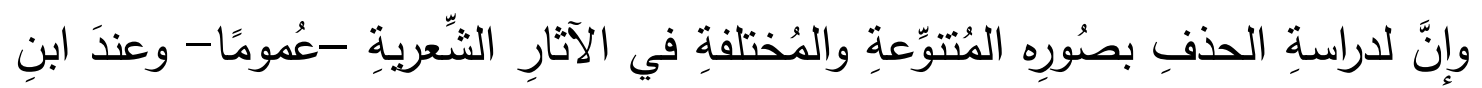

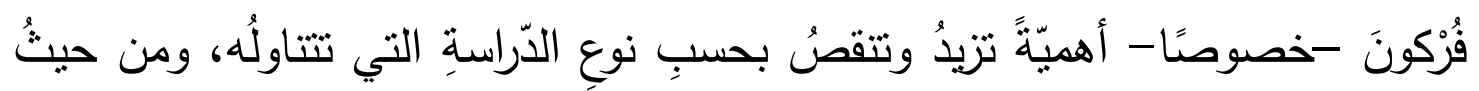

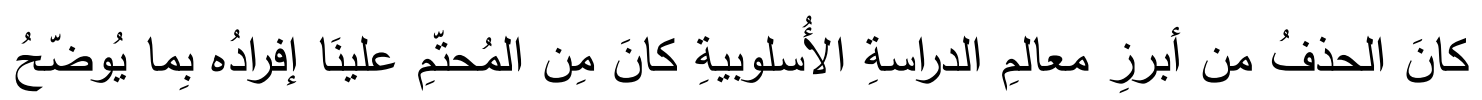

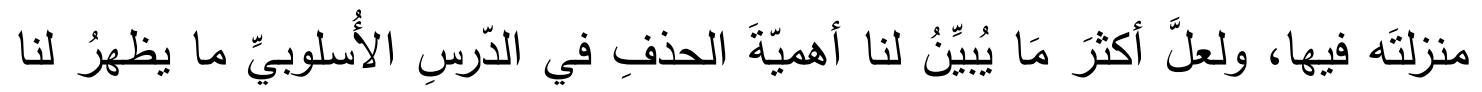

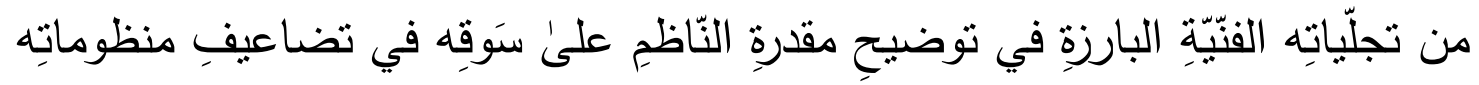

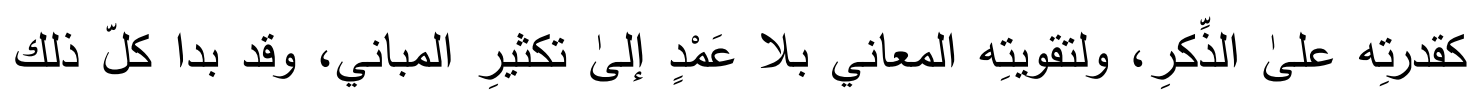

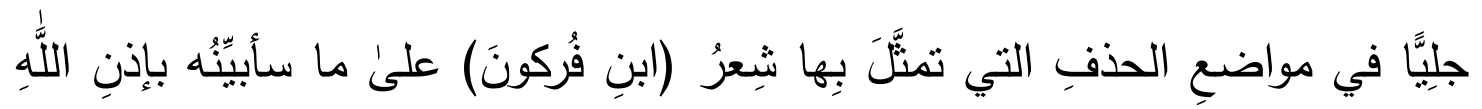

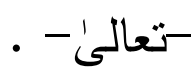

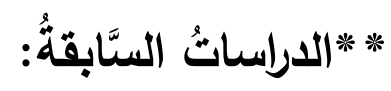

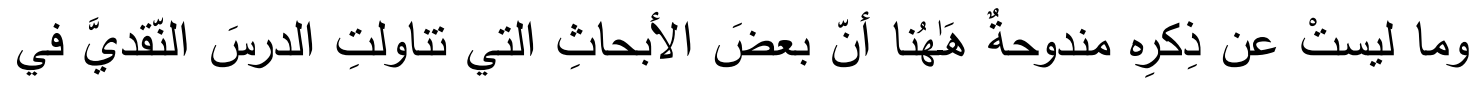

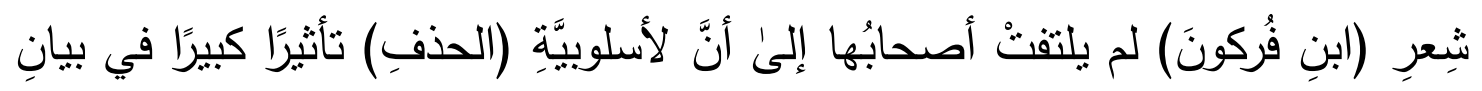

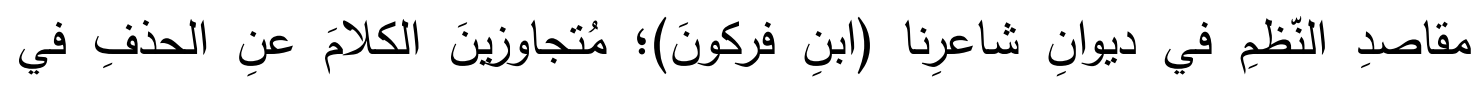

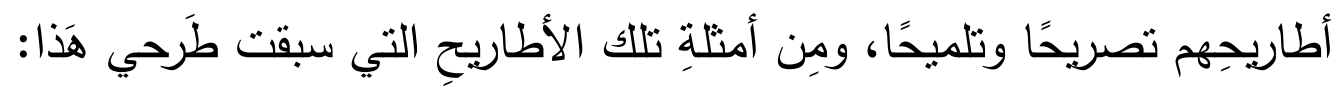
1- - (ابن فُرْكون شاعرًا) رسالة ماجستير، للباحث: أحمد عبدالمغني حسن شرف، إنشراف الأستاذ الدكتور: عبداللطيف عبدالحليم، كلية دار العلوم، جامعة القاهرة، (99 (م))، جيثُ لم يعمدِ الباحثُ إلى القولِ في عُصرِ الحذف. 
r- - (ابن فُركون الأندلسيّ شاعرُ غرناطة) للباحث: قاسم القحطاني، طبعة دار

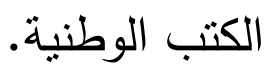

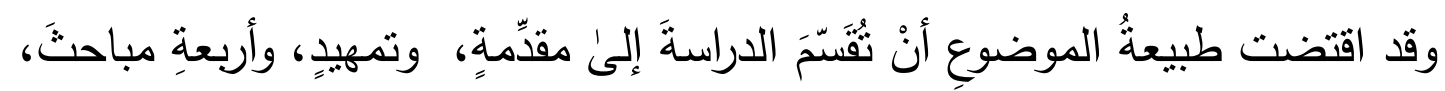

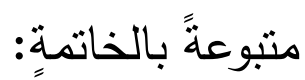
- المبحثُ الأوَّلُ: الحذفُ في التَّكيبٍ الإسناديِّ.

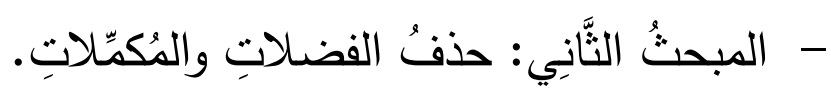
- المبحثُ الثَّالثُ: الحذفُ في الحُروفِ. - المبحثُ الرَّابحُ: الحذفُ في التَّكيبِ الثنَّرطيِّ.

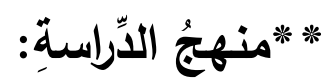

وقد اعتمدتُ في هَذه المباحثِ على المنهج الأسلوبيِّ الذي يُعنى برصد البُنئ اللغويةِ والتراكيبِ الإسناديةِ والمهيمناتِ الأسلوبيةِ ودراستِهِا وتحليلِهِا.

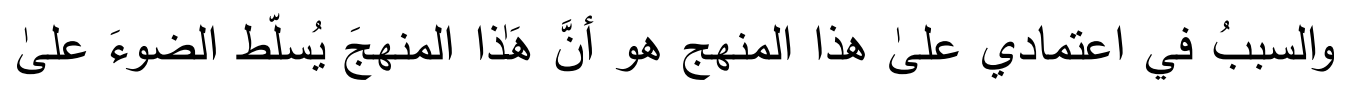

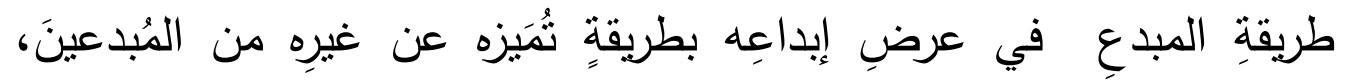

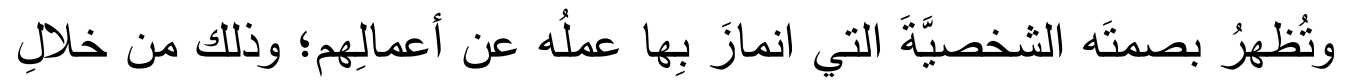
الوقوفِ على الظواهرِ الأسلوبيةِ البارزة في عملِه الأدبيِّ .

أولًا : التمهيدُ (أ)/التعريفُ بَالثُاعرِ (ابنِ فُرْكون) الغرناطيّ:

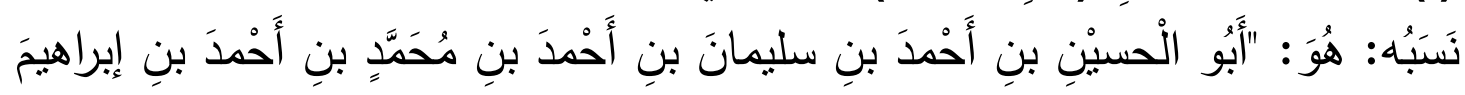

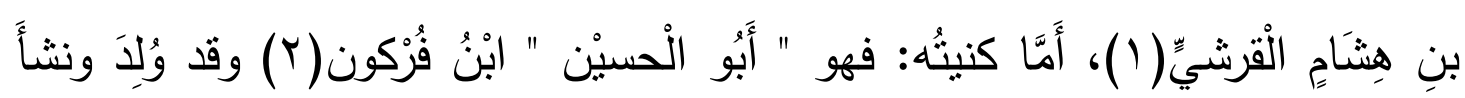

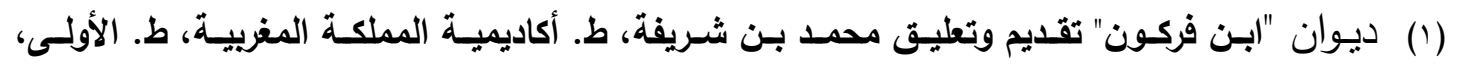

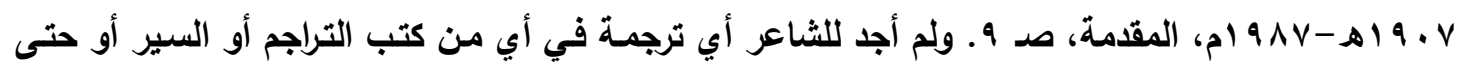

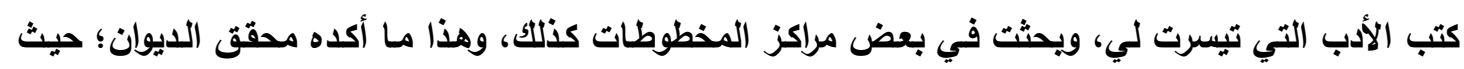

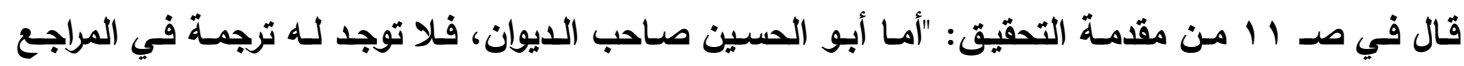

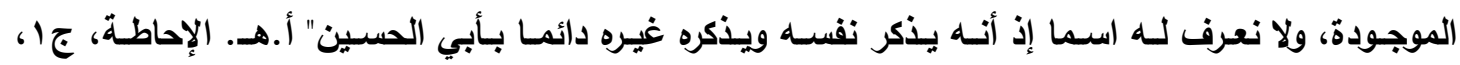




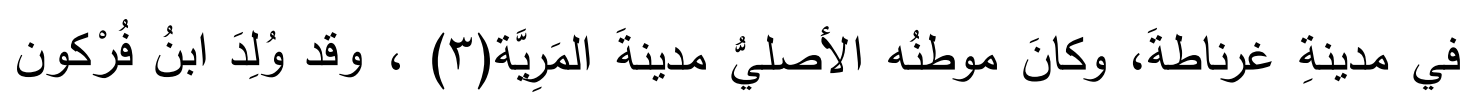

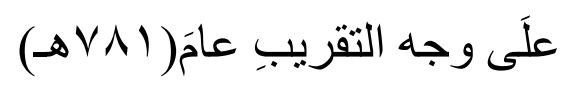

أَسْرَنُهُ:

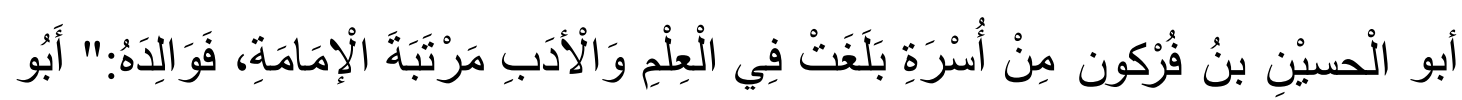

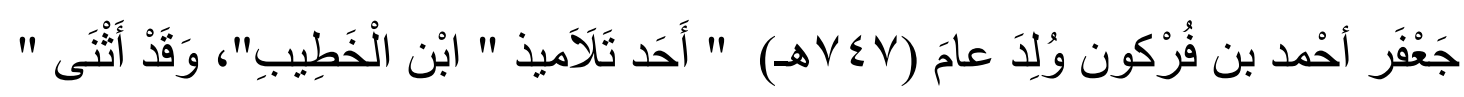

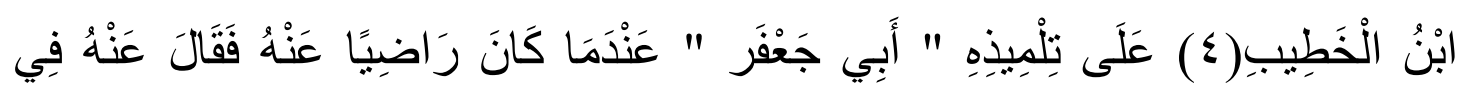

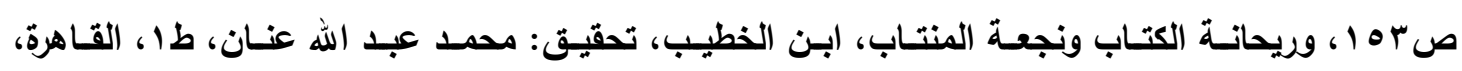

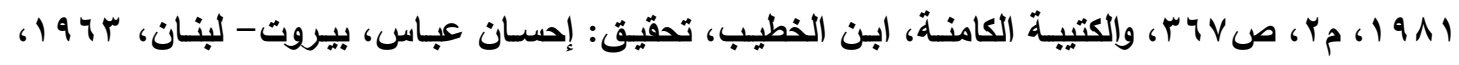

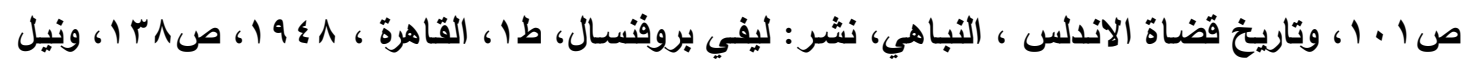

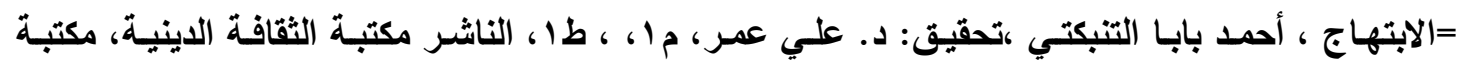

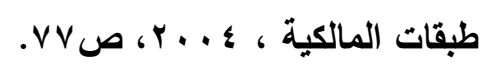

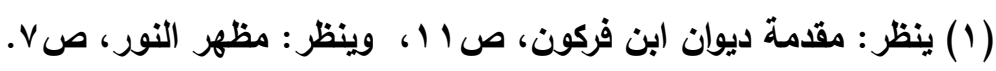

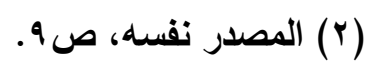

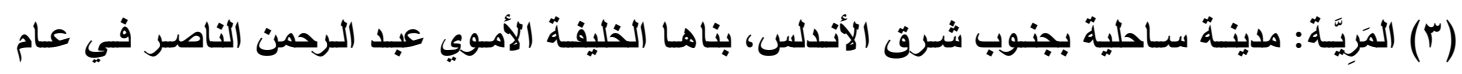

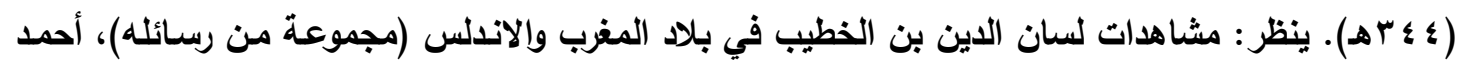

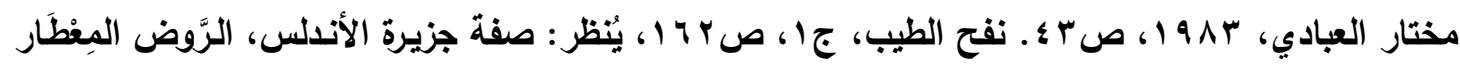

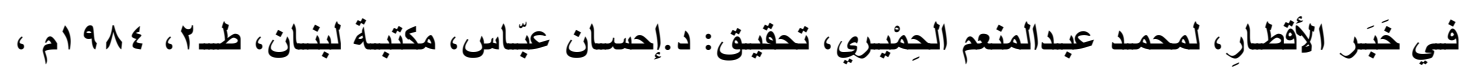

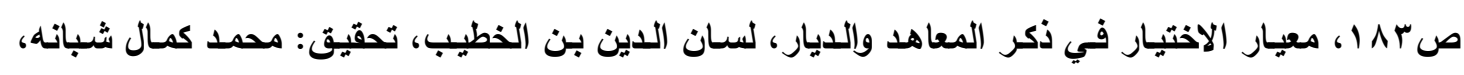

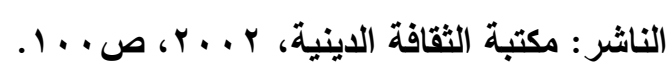

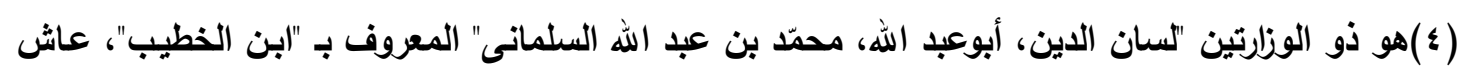

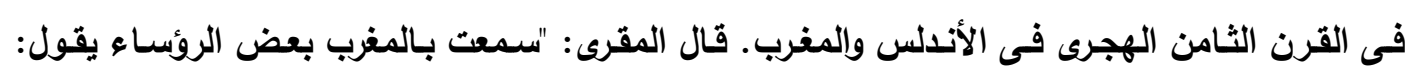

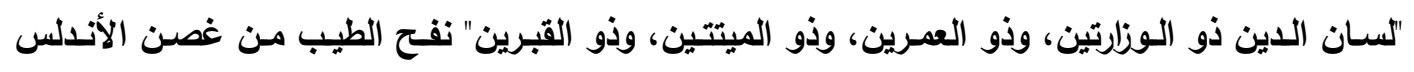

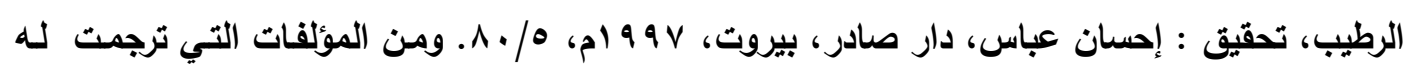

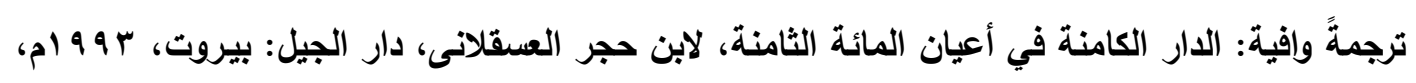

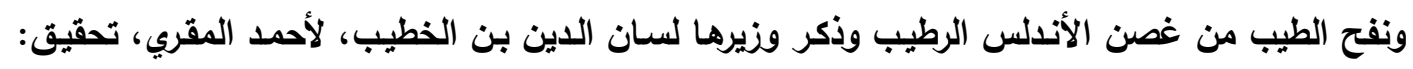

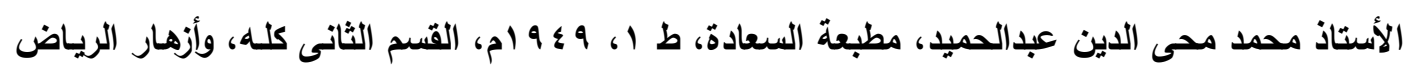

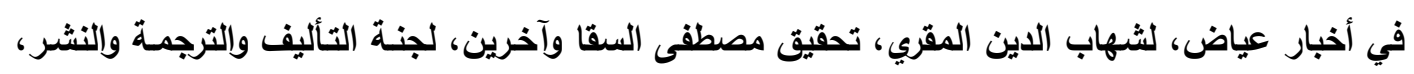

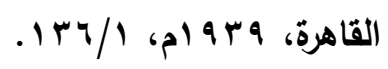




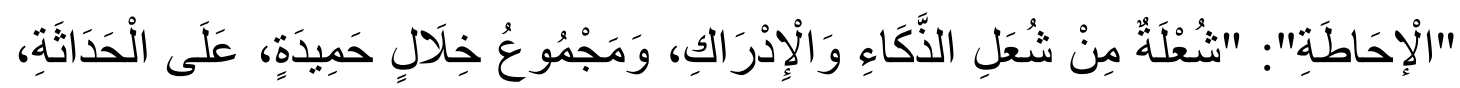

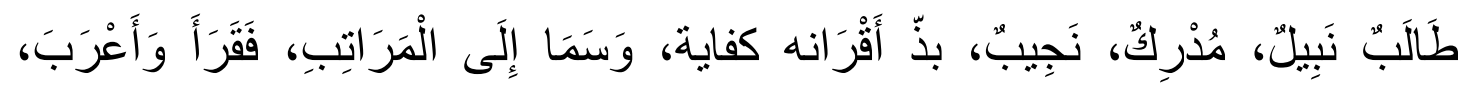

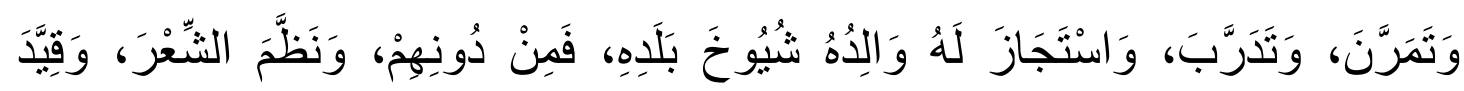

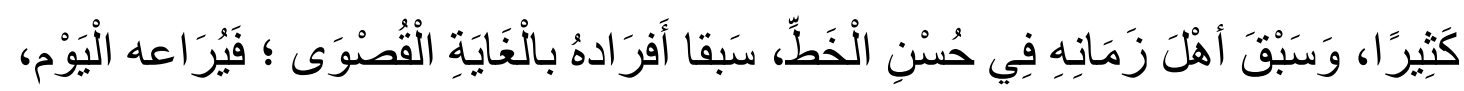

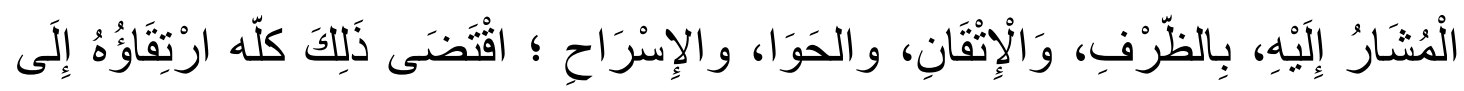

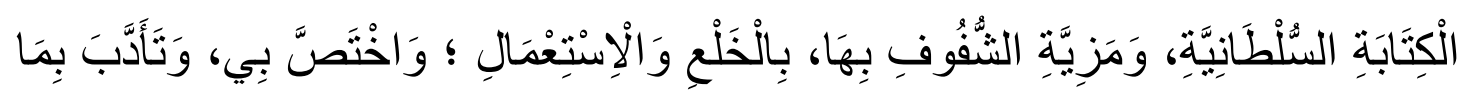

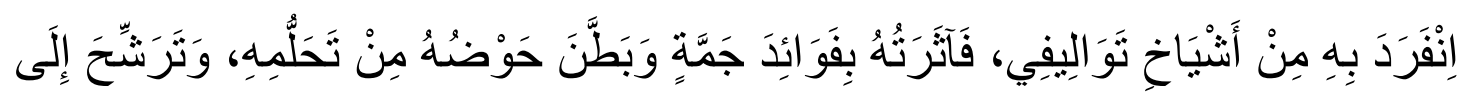

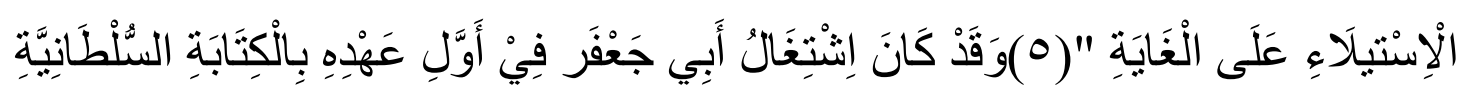

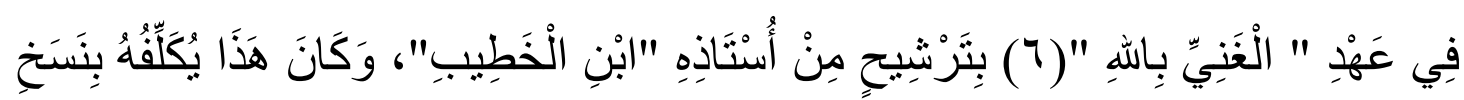

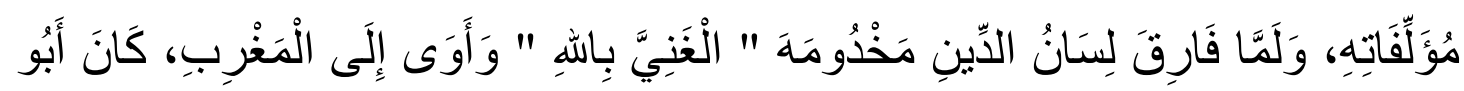

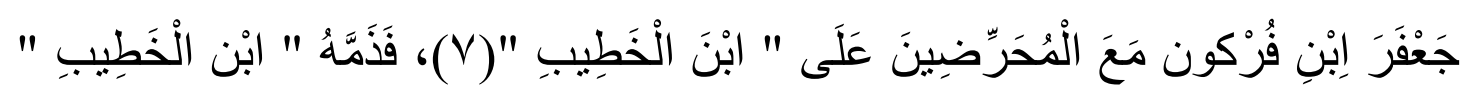

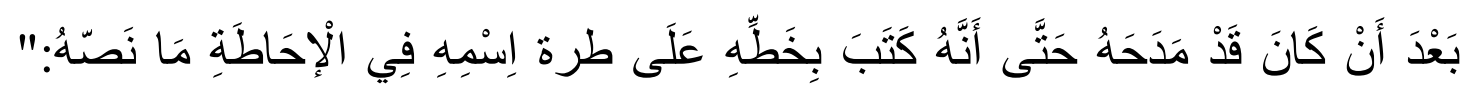

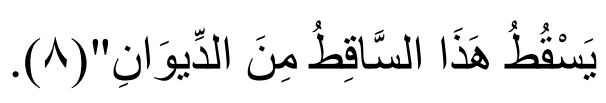

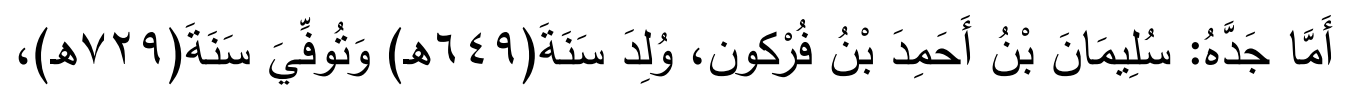

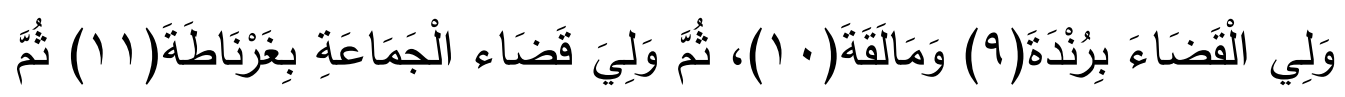

(•) - "الإحاطة في أخبار غرناطة" لسان الدين بن الخطيب، تحقيق: محمد عبد الله عنان، ط. مكتبة الخانجي

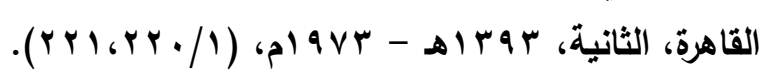

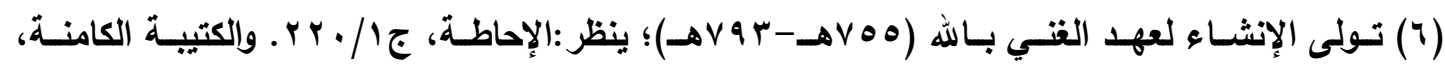

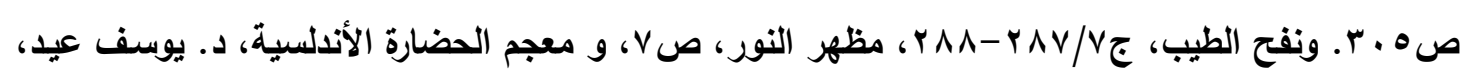

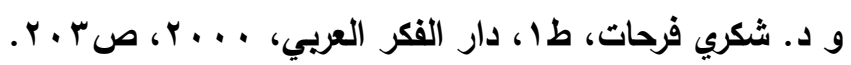

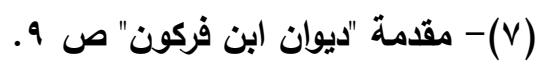

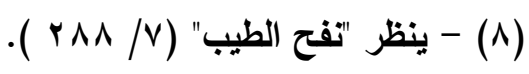

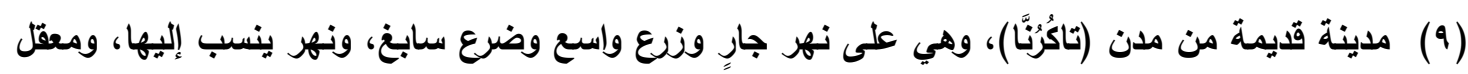

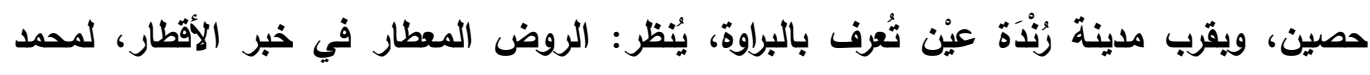

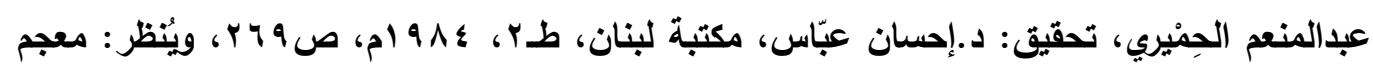

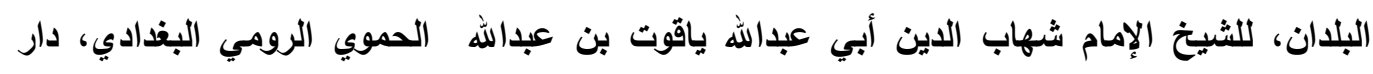




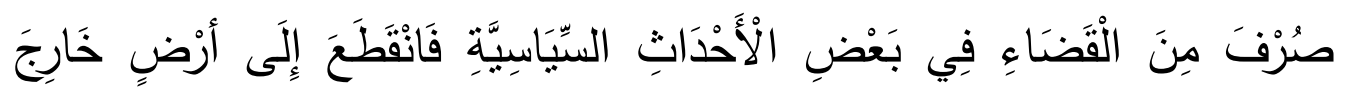

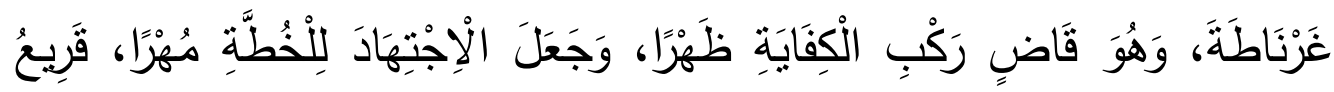

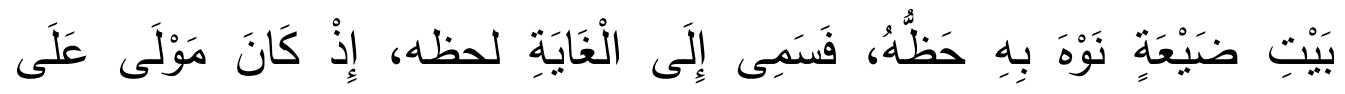

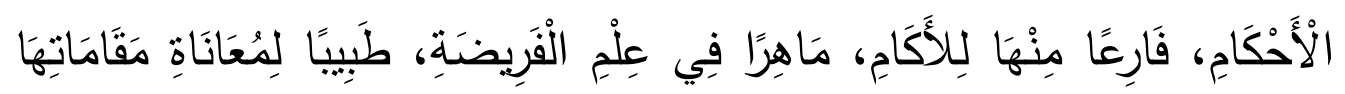

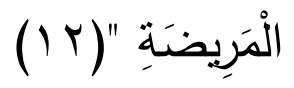

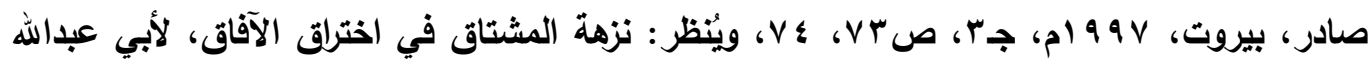

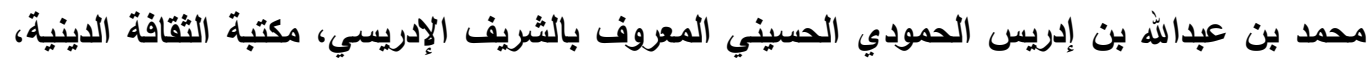

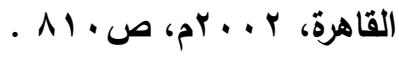

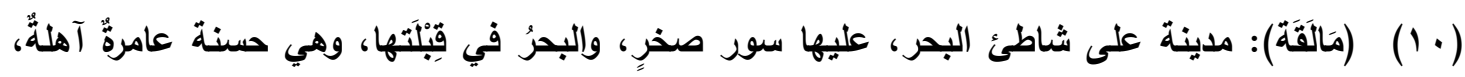

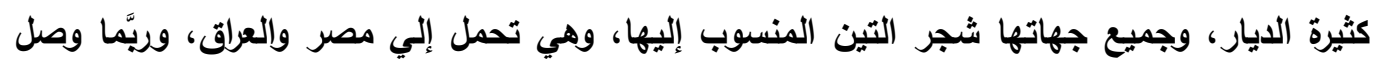

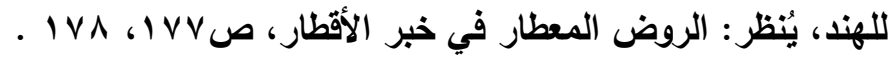

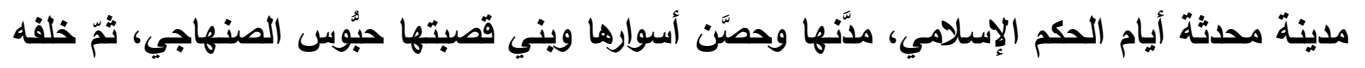

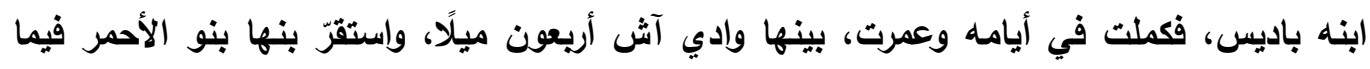

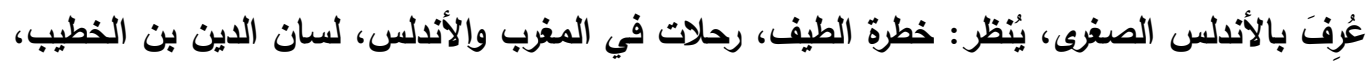

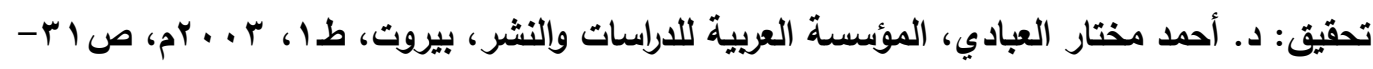

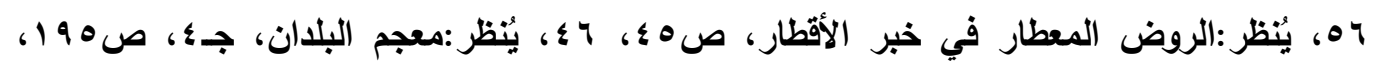

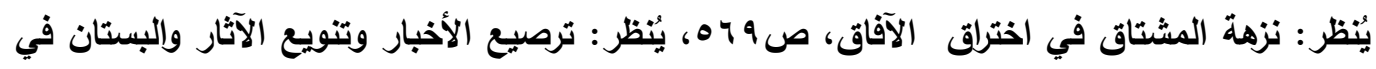

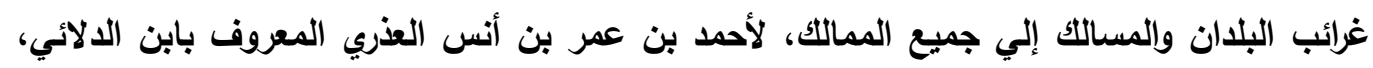

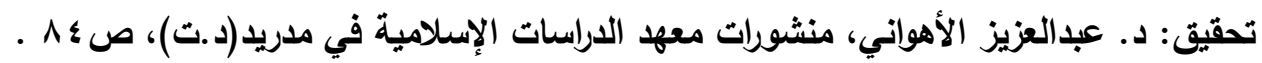

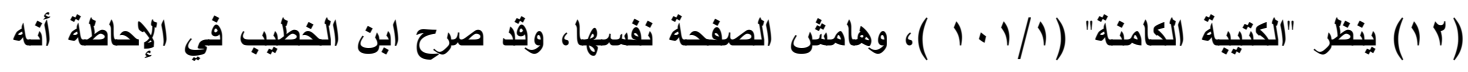

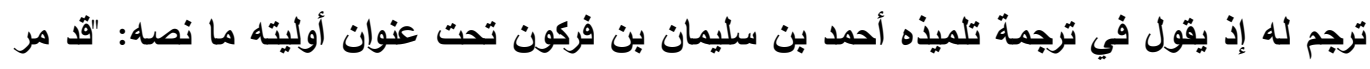

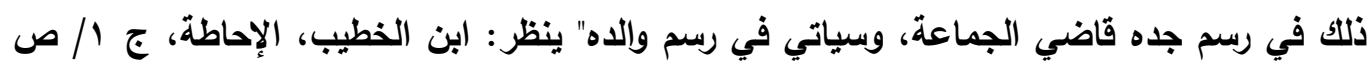




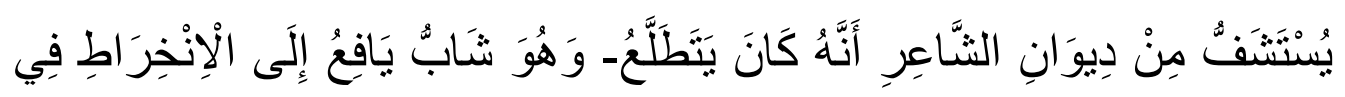

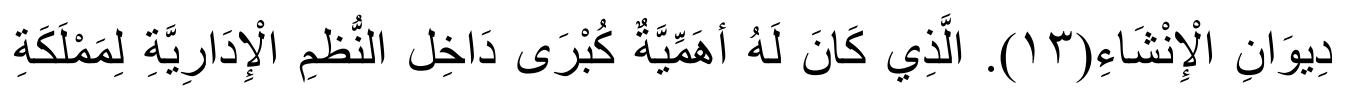

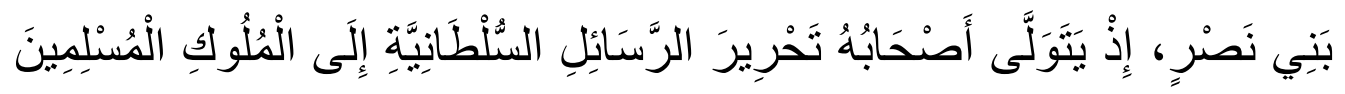

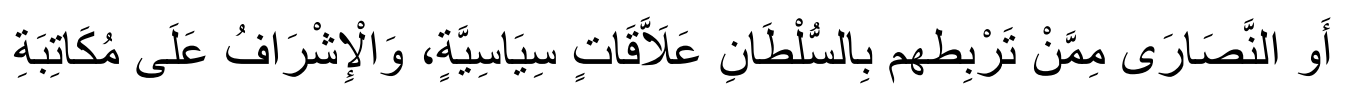

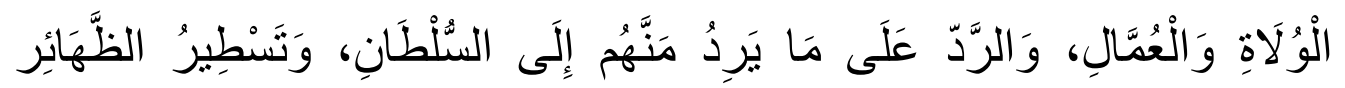

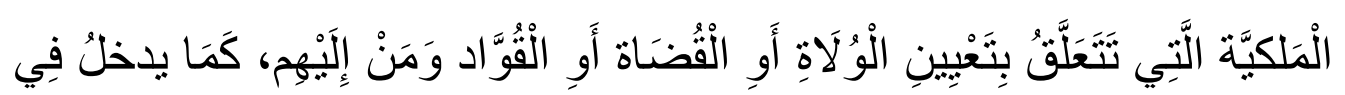

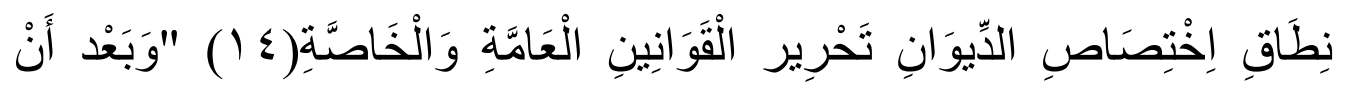

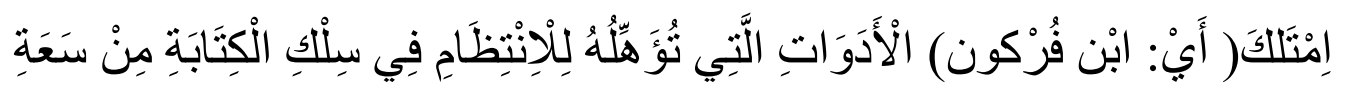

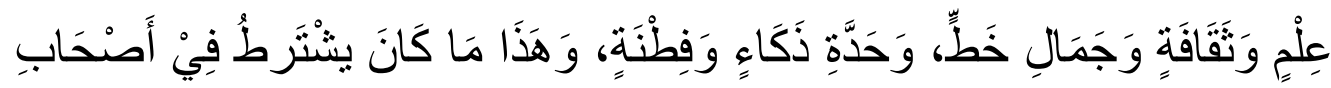

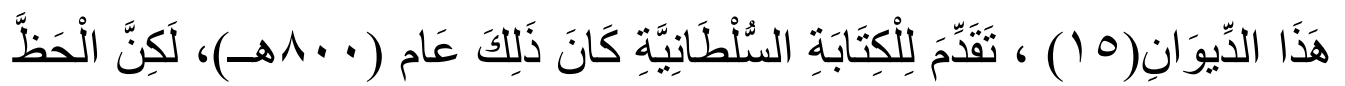

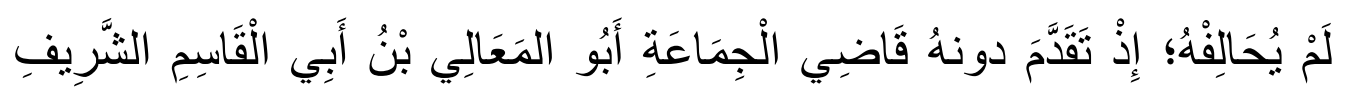

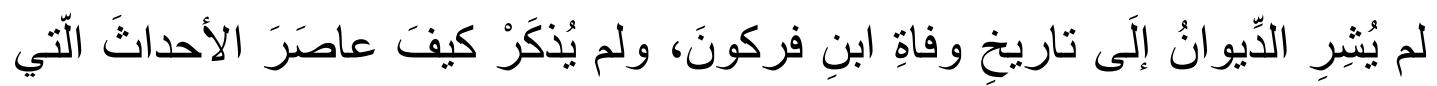

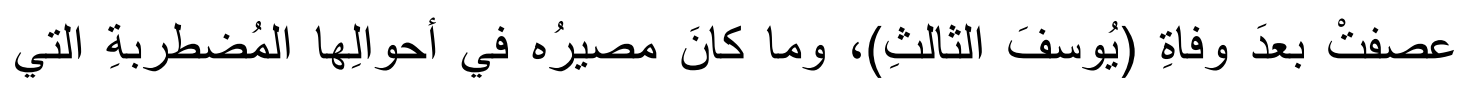

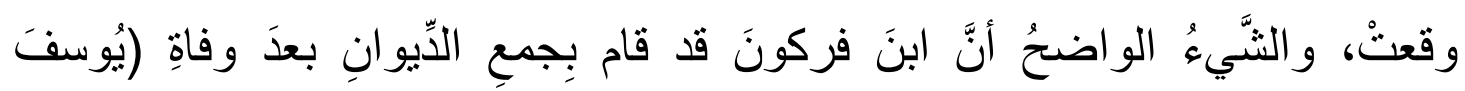

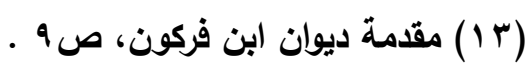

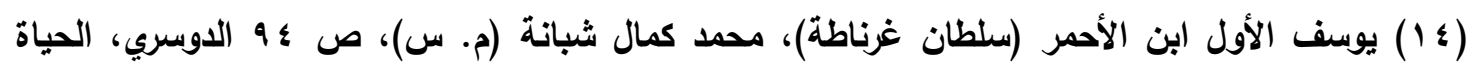

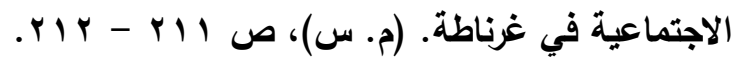

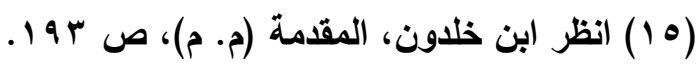

$$
\begin{aligned}
& \text { (17 (1) ) تقدمت ترجمته. }
\end{aligned}
$$




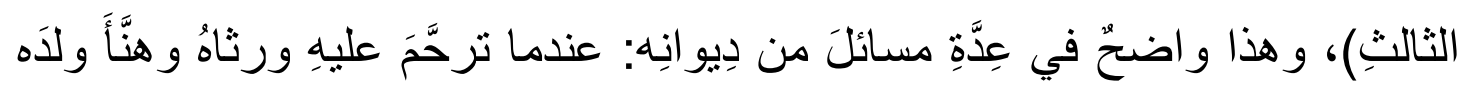

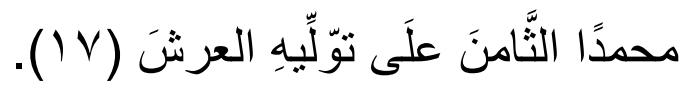

وعلَى ما يبدو أنَّ نَجََ ابنِ فركونَ قد أفلَ بعدَ وفاةِ (يُوسفَ الثالثِ) ولاسيَّما بعدما استطاعَ مُحمَّدُ النَّاسعُ المُلقَّبُ بالأيسرِ الاستيلاءَ على العرشِ في عامِ

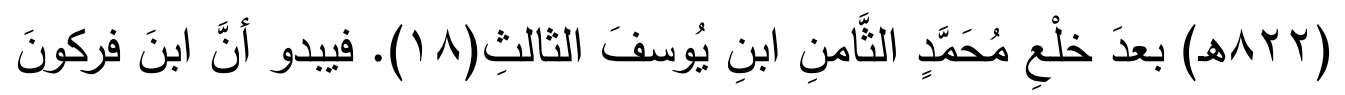

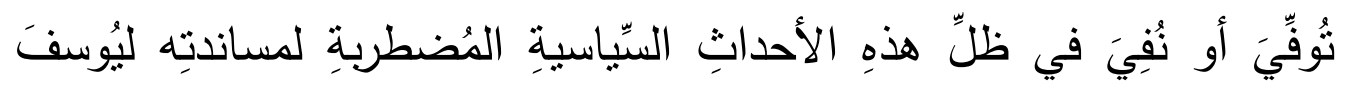
الثالثِ وولِده مِن بعدِه، ومَحَ ما كانَ مِن أنَّ يَحيَى بنَ عاصٍِ الغرناطِيِّ

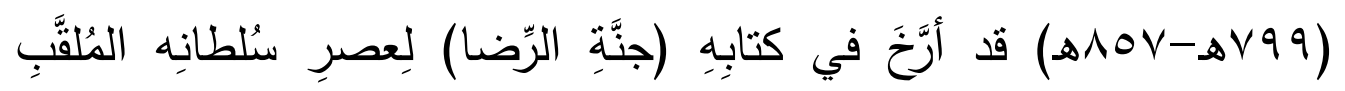
بالأيسرِ وذَكَرَ معاصرِيهِ(9 (1)، إلَّا أنَّهَ لم يَذَكُرِ ابنَ فركونَ من ضمنِهم، وقد

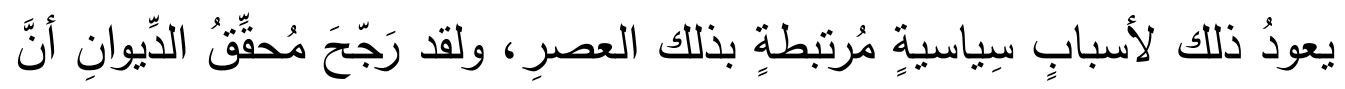
ابنَ عاصةٍ قد ترجمَ لحياةِ ابنِ فركونَ في كتابِه (الرَّوضِ الأريضِ) إلّاّ أنَّهَ

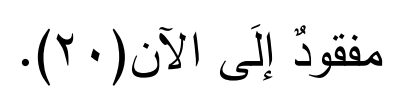

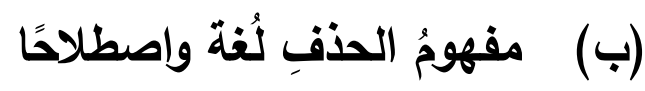

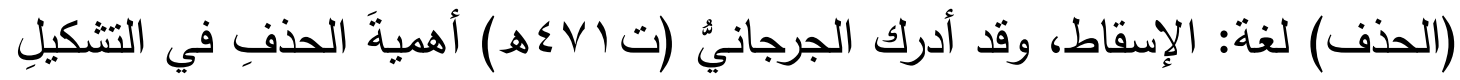

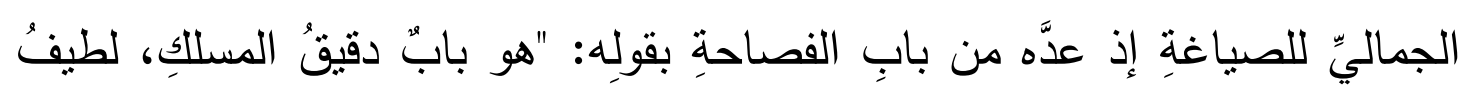

$$
\text { (IV) }
$$

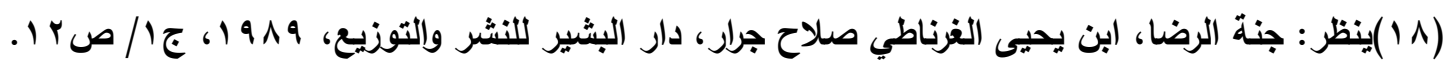

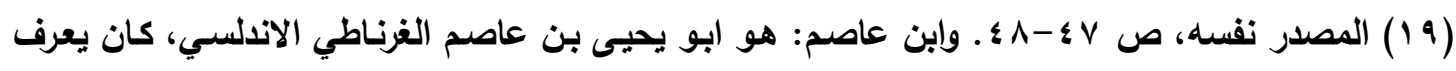

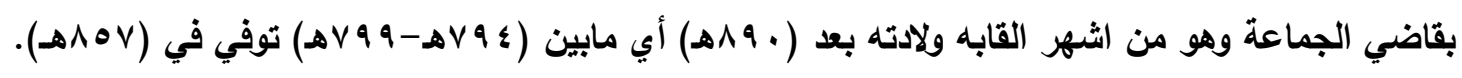

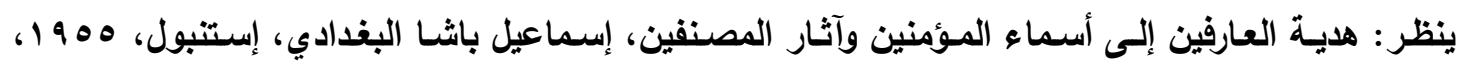

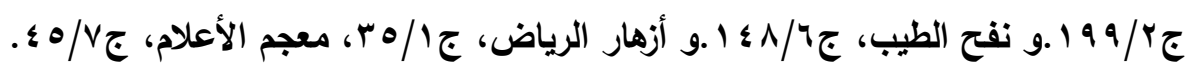

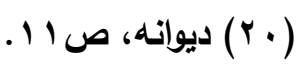




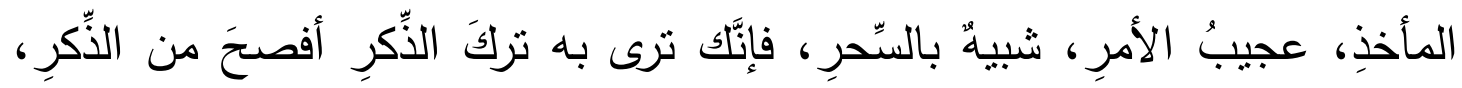

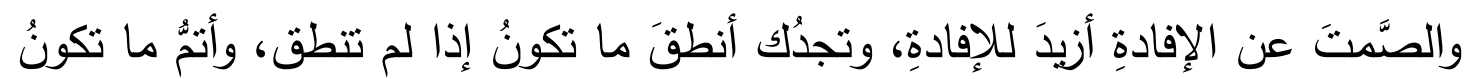

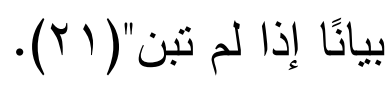

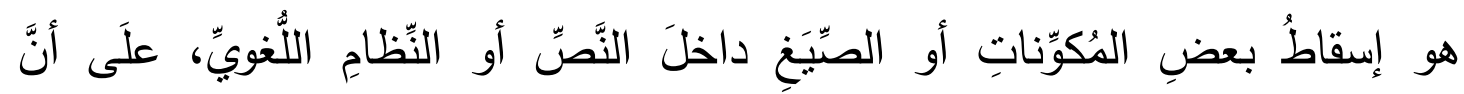

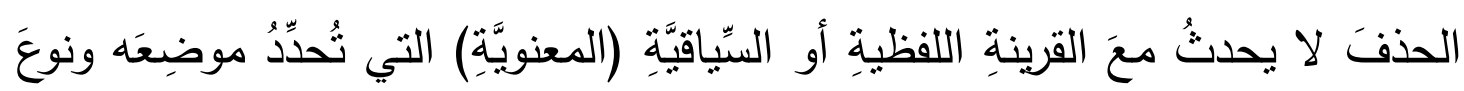

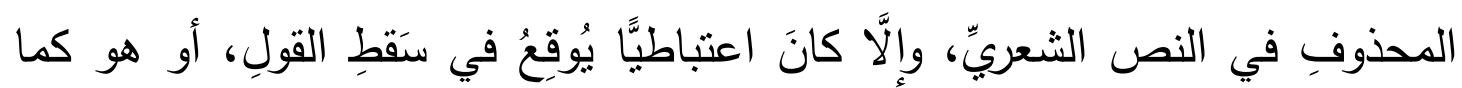

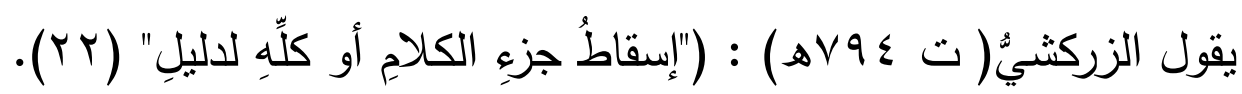

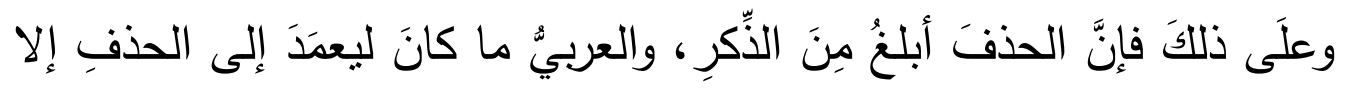

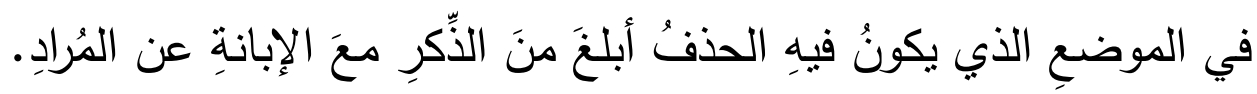

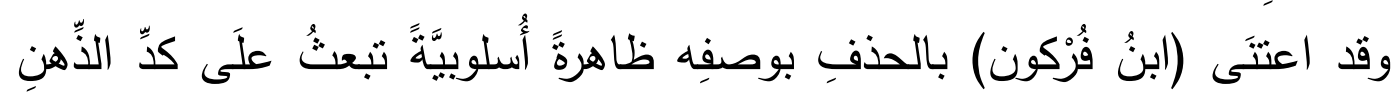

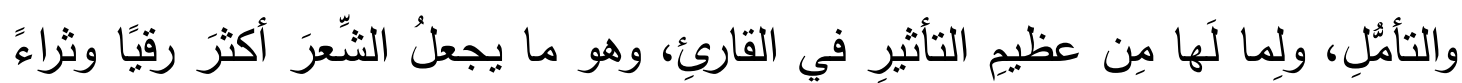
في الدلالةِ بقليٍٍ من الألفاظِ، فهو يعطي الكلامَ إبداعًا، بعيدًا عن الثقريريةِ الدحضةِ

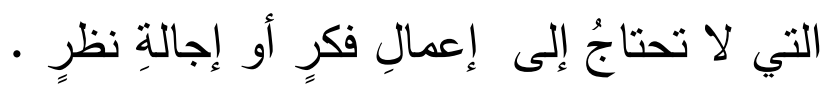

والحذفْ: "بعتمدُ علَى الحضورِ والغيابٍ للعناصرِ اللغويةِ، فهو غيابٌ لعنصرٍ

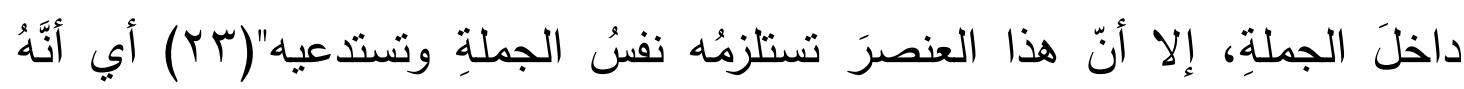

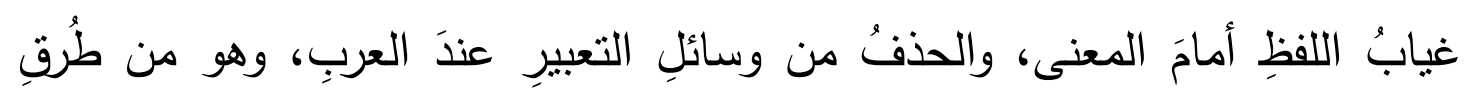

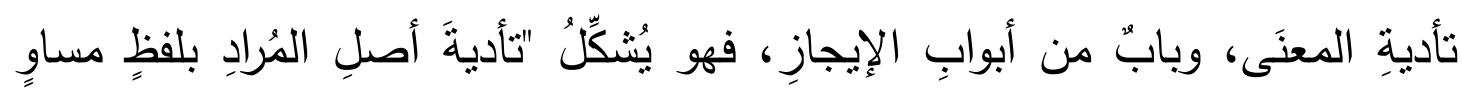

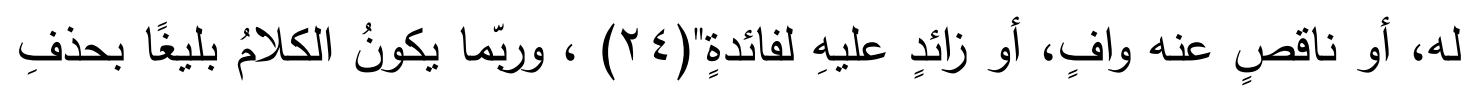

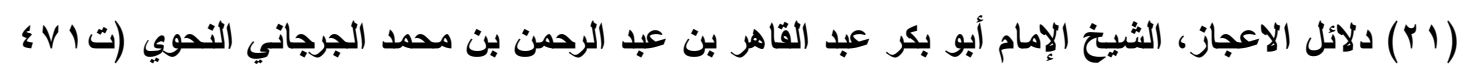

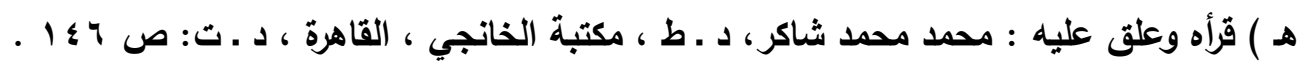

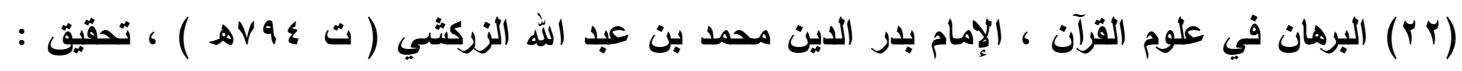

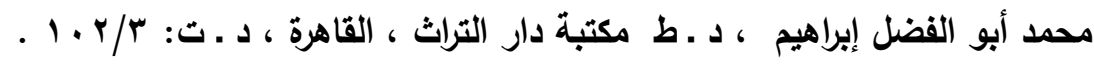

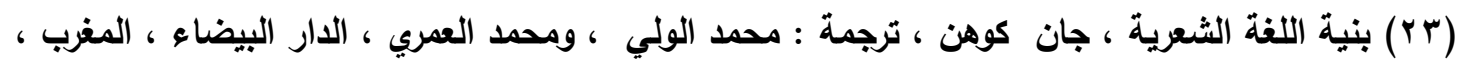

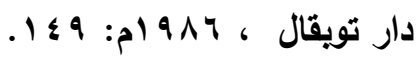

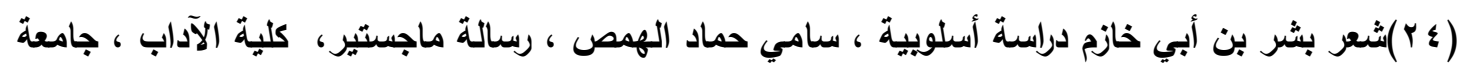

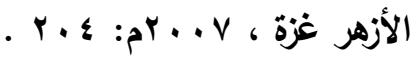




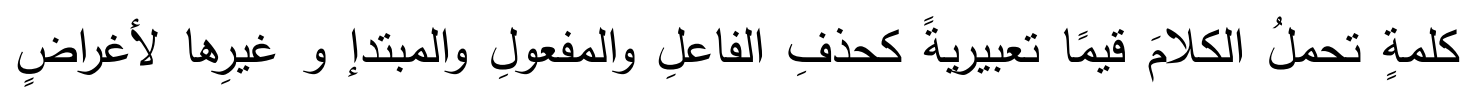

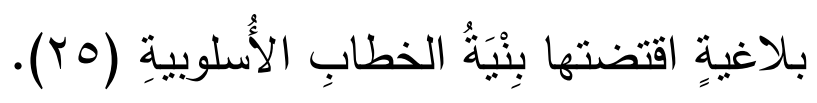

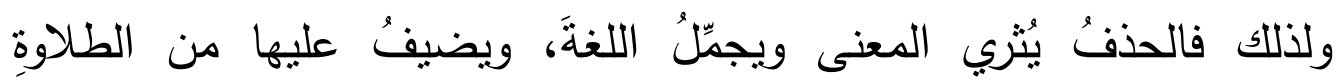

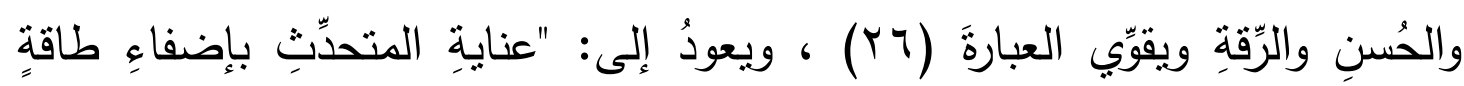

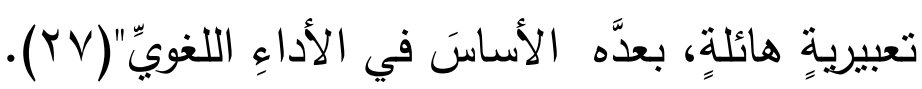

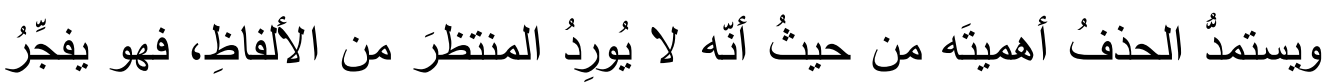

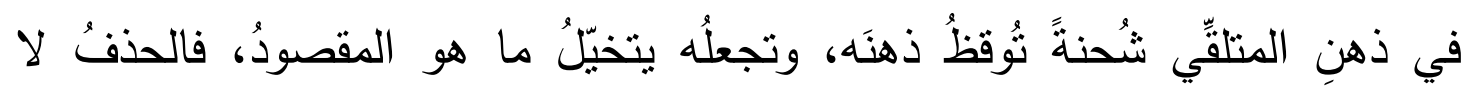

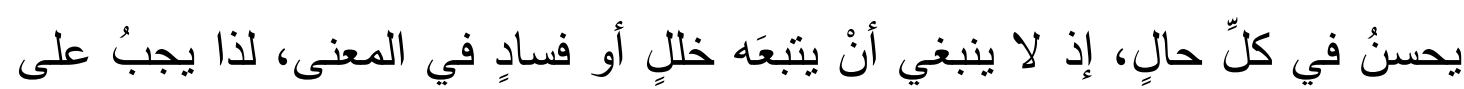

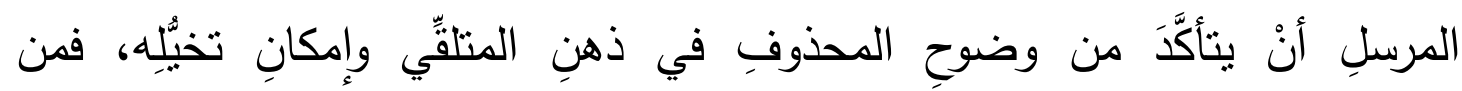

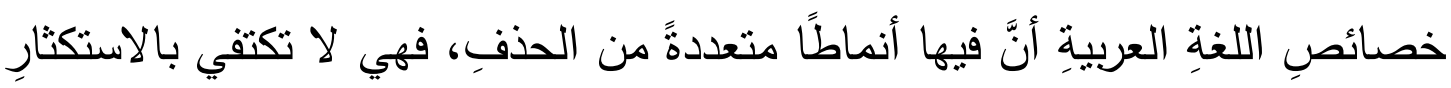

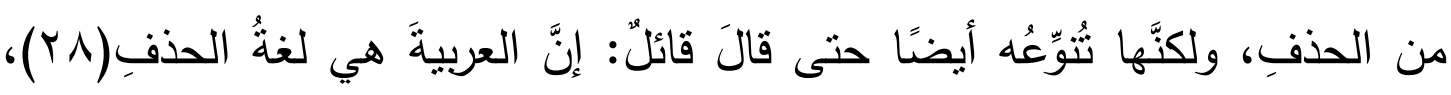

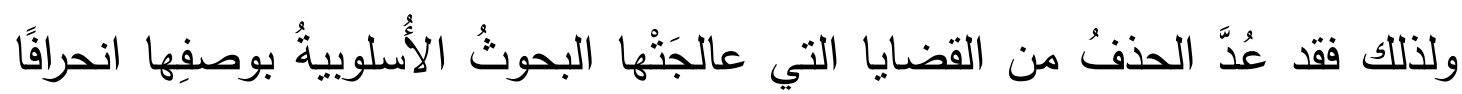

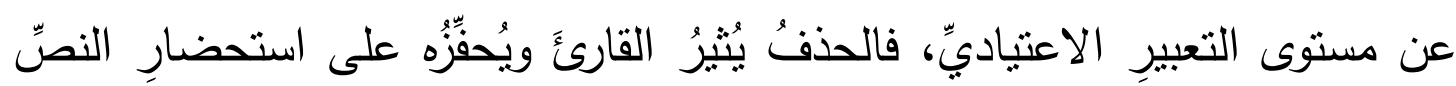

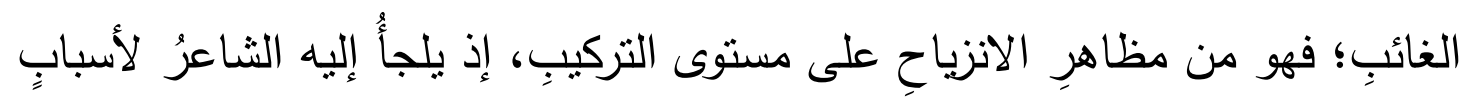

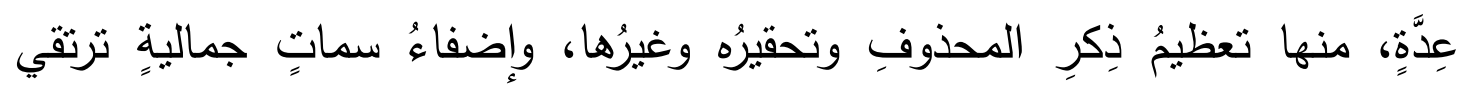

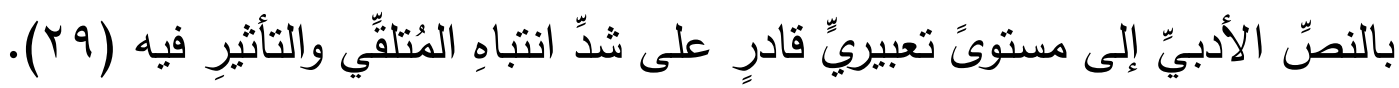

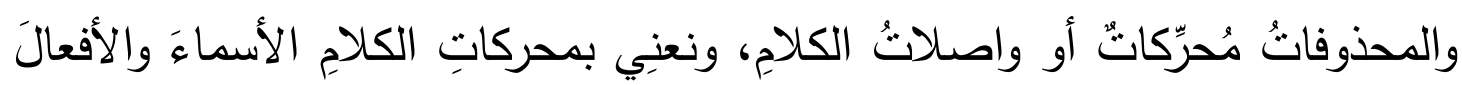

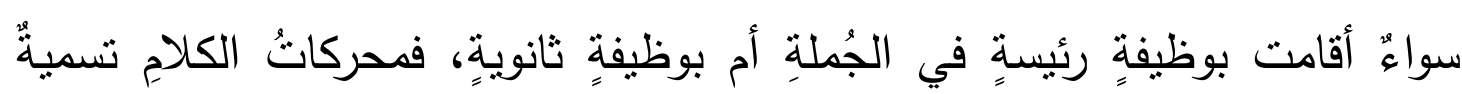

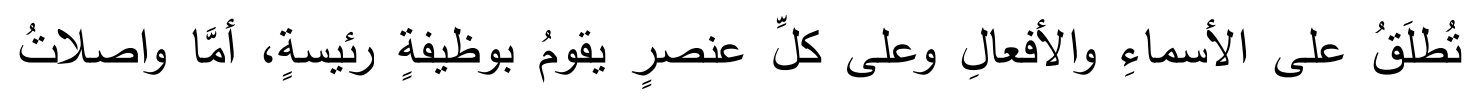

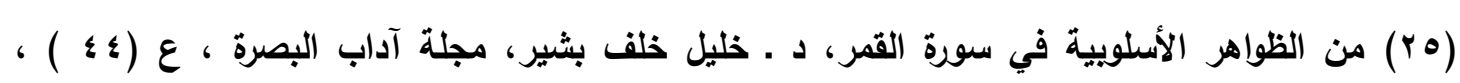

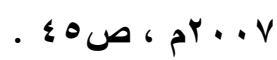

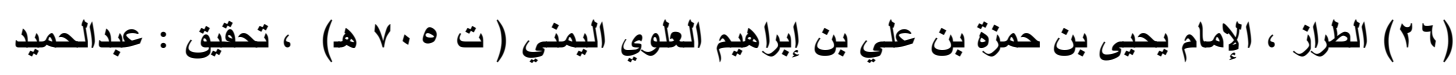

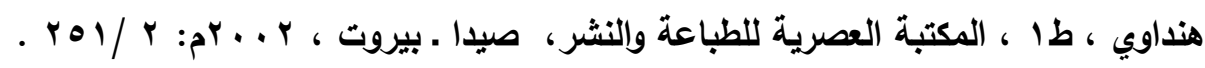

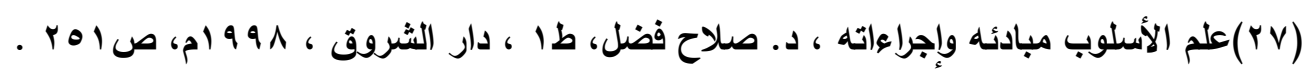

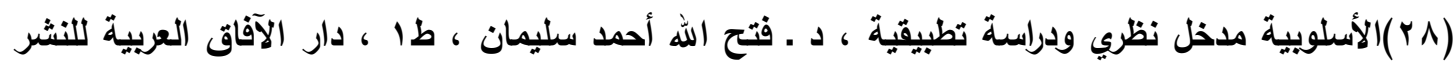

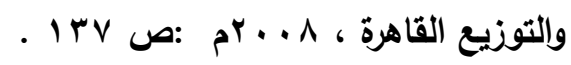

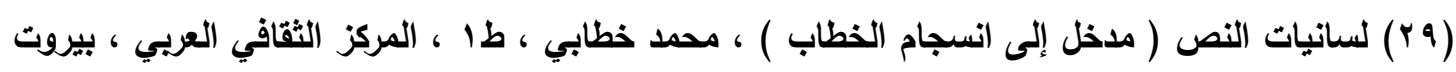




\begin{tabular}{|c|c|c|c|}
\hline \multicolumn{4}{|c|}{ أولا: الحذف في التركيب الإسنادي } \\
\hline النسبةُ & 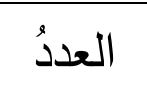 & نوعُ المحذوفِ & المسلسلُ \\
\hline$\% \varepsilon 1 . . V$ & $r \cdot \Sigma T$ & المبتدأ & 1 \\
\hline$\%$ \% & roqV & الخبر & r \\
\hline$\% \wedge .74$ & 947 & الفاعل & $r$ \\
\hline$\%$ r.ro & $r \leq 1$ & نائب الفاعل & $\varepsilon$ \\
\hline$\% 1 Y . .7$ & 190 & 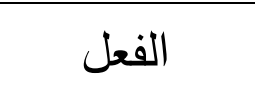 & 0 \\
\hline$\% 1 \ldots$ & $V \varepsilon 1 \wedge$ & المجموع & \\
\hline
\end{tabular}

الكلاجٍ فهي الحروفُ والأدواتُ، وهذا التقسيُ يسّهُُ علينا دراسةَ أقسامِ الكلاجٍ باعتمادِ

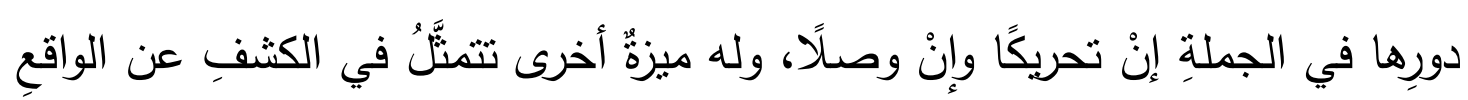

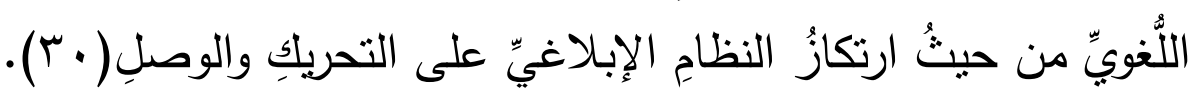

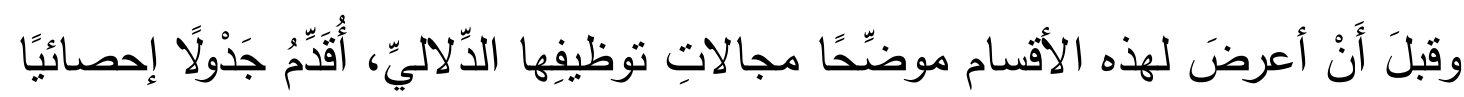

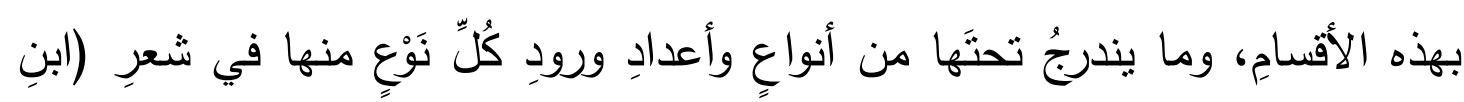
فُرْكون)، وذللكَ على النَّحْوِ الآتي:-

\begin{tabular}{|c|c|c|c|}
\hline \multicolumn{4}{|c|}{ ثانيًا: حذف الفضلات والمكملات } \\
\hline النسبةُُ & العددُ & نوعُ المحذوفِ & المسلسلُ \\
\hline$\%$ \%.Аq & Or & حذف المضاف إليه & 1 \\
\hline$\% \leq \Lambda . \mid \vee$ & VTr & حذف المفعول بـ & r \\
\hline$\% \backslash 0 . \varepsilon$. & $r \leq \varepsilon$ & حذف الموصوف & r \\
\hline$\%$ \%.० & 07 & حذف تمبيز كم & $\varepsilon$ \\
\hline$\% 1 \ldots$ & $10 \wedge \varepsilon$ & المجموع & \\
\hline
\end{tabular}

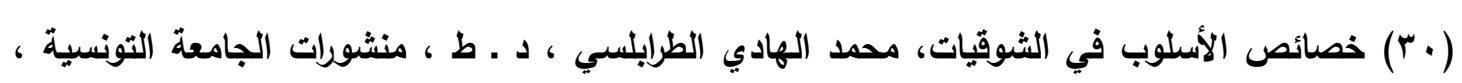

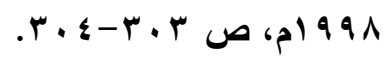




\begin{tabular}{|c|c|c|c|c|}
\hline \multicolumn{5}{|c|}{ ثَالثًا: الحذفتُ في الحرفِ } \\
\hline النسبة & العدد & \multicolumn{2}{|c|}{ نوع المحذوف } & المسلسل \\
\hline$\% 07.10$ & r. & \multicolumn{2}{|c|}{ حذف (رُبَّ) } & 1 \\
\hline$\% \vee . \wedge 9$ & $\leqslant 0$ & \multicolumn{2}{|c|}{ حذف (حرف النون) } & r \\
\hline$\%$ IY.A. & $v r$ & \multicolumn{2}{|c|}{ حذف أداة النداء } & $r$ \\
\hline \%rr.ıт & Trt & \multicolumn{2}{|c|}{ حذف أداة الاستقهام } & $\varepsilon$ \\
\hline$\% 1 \ldots$ & ov. & \multicolumn{2}{|c|}{ المجموع } & \\
\hline \multicolumn{5}{|c|}{ لربعًا: الحذفُ في التركيبٍ الشرطيّ } \\
\hline النسبةُُ & \multicolumn{2}{|c|}{ العددُ } & نوعُ المحذوفِ & 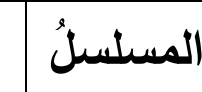 \\
\hline$\% 1 \ldots$ & \multicolumn{2}{|c|}{$\varepsilon r \wedge$} & جواب الشرط & 1 \\
\hline$\% 1 \ldots$ & \multicolumn{2}{|c|}{$\varepsilon r \wedge$} & المجموع & \\
\hline
\end{tabular}

المبحثُ الأوَّلُ: الحذفُ في التَّكيبِ الإسناديِّ

(حذف المبتدا!)

إنَّ نَرَكَ المسندِ إليهِه عند قيامِ قرينةٍ تدلُ عليه يُحقِّقُ إيجازَ العبارة، وصونَها عن المَطلَِ، كما يُعينُ علَى إستتارةٍ الفِكِِ وحتِّه على الولوجِ إلىى أعماقِ المعنى لاسنتباطِ الخافيَ منه من خلالِ قربنةِة السياقِ أو اللازمِ المذكورِ، ويحذفُ المُسند إليهِ لأمورٍ

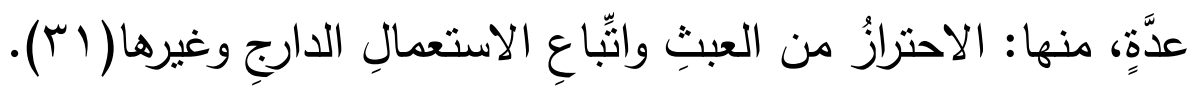
وقد تعدَّدَ المحذوفُ الإسميٌٌ لقرينةٍة دالةٍ عليه، وعَمَدَ الثَعراءُ إلىى الحذفِ بكلِّ ما أجازته اللغةُُ؛ فحذفوا وأوجزوا فبلغوا الغايةً في المعنى، فحذقوا المبتداً مُقًََّاً بالضميرِ

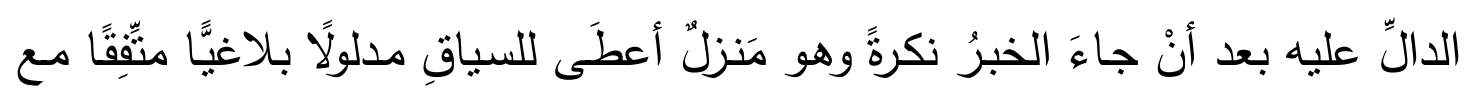
( آץ) مدخل إلى البلاغة العربية ( علم المعاني ـ علم البيان ـ علم البديع )، دـ ـ يوسف أبو العدوس، طا، دار

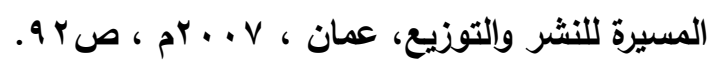


مقاصدِ العربِ في كلامِهم، ومنحَ للمخاطبِ الحربةََ في التقديرِ، مع تحديدِ المحذوفِ بشخصِ الممدوحِ أو المقصودِ دونَ غيرِه.

ويأتي حذفُ المُسندِ إليه في معظٍِ النماذج لغرضٍ بلاغيٍٍ مُعيَّنٍ، يُعنَى غالبًا

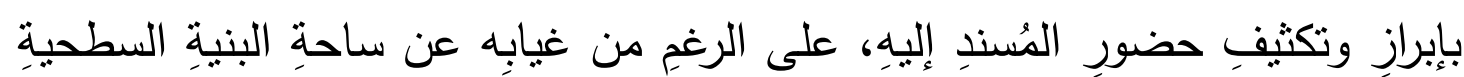

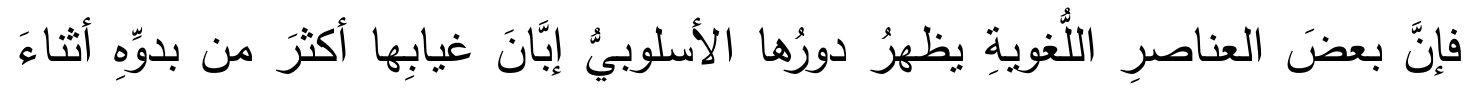

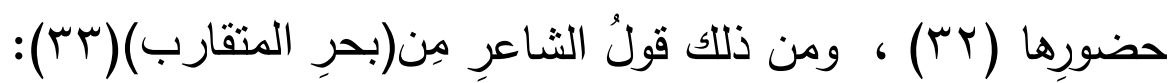

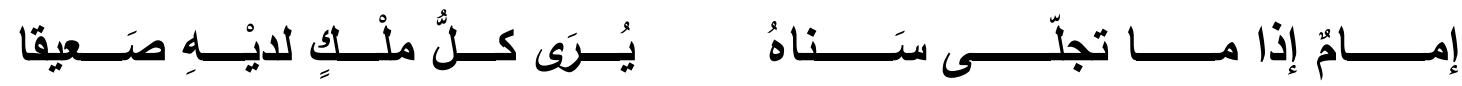

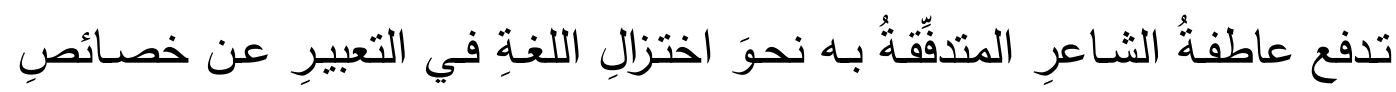
الممدوحِ التي تحلّى بها؛ فالمحذوفُ هُنا هو المبتدأُ والتقديرُ : (هو إمامُ)، فهو دونَ

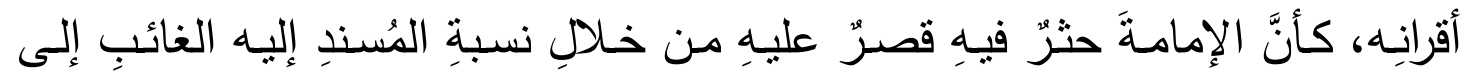
المُسندِ المذكورِ بقريتةِة حاجةِ السياقِ إلَى كليهما؛ إذ لا يقومُ الكلامُ ولا يتمُّم معناهُ إلَّا

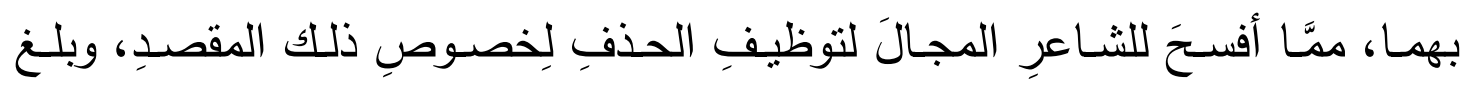

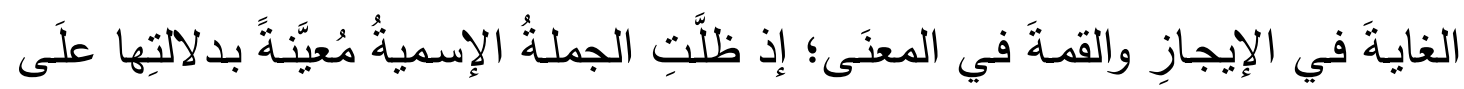
الثباتِ والدواجِ، وبهذا أفادَ الحذفُ في إعمالِ وكدِّ فكرِ المتلقِّي من أجلِ البحثِ عن

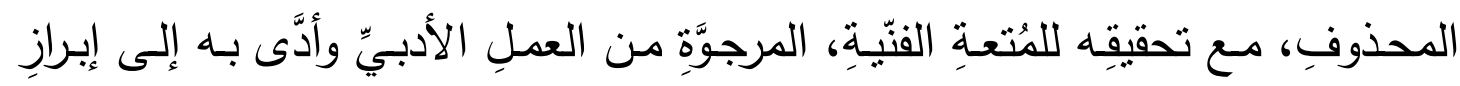

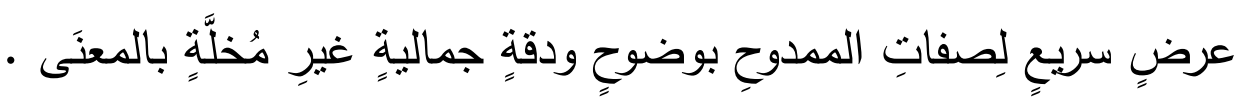
ويقول الثناعر(من بحر الطويل) (؟)

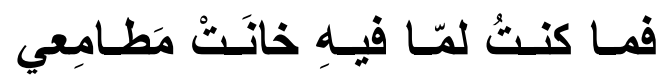

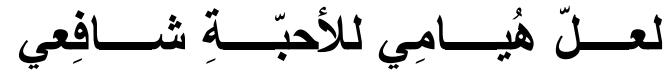

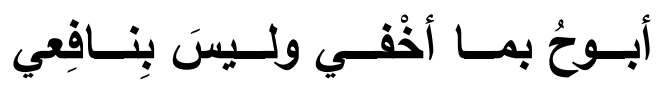

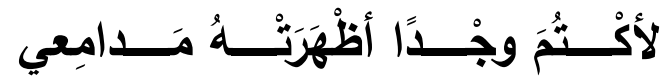
(ץ (ץ) جلية الإفراد والتركيب في النقا العربي القديم، د ـ محمد عبد المطلب طا، الثركة المصرية العالمية

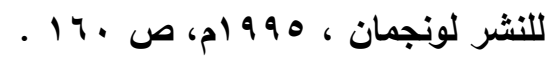

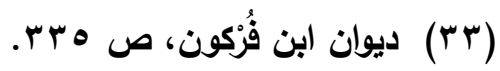

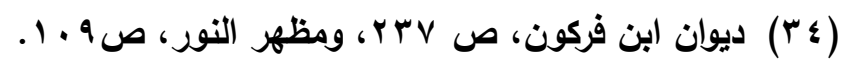


وفي قوله: "وليسَ بِنافِعِي" حذفَ الثناعرُ اسحَ (ليس) على تقديرِ :وليسَ البوحُ

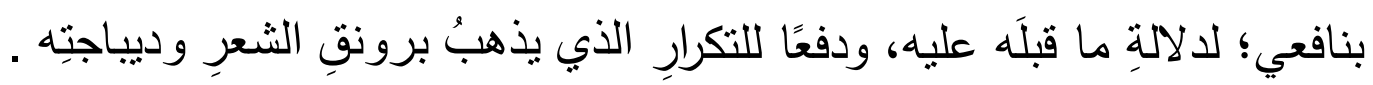

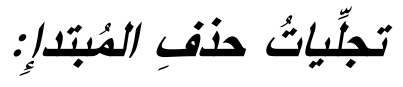

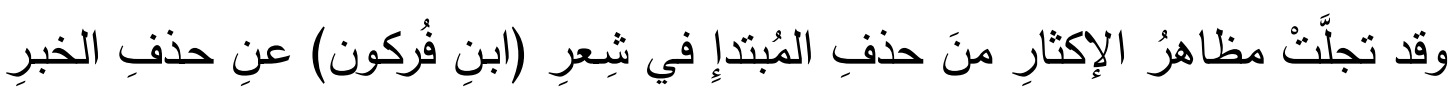

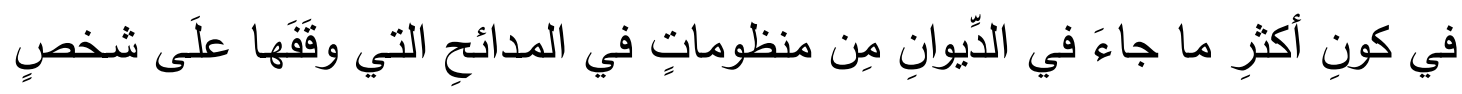

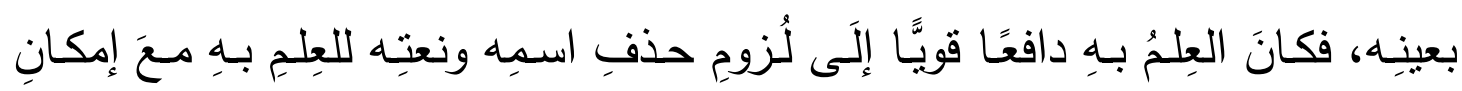

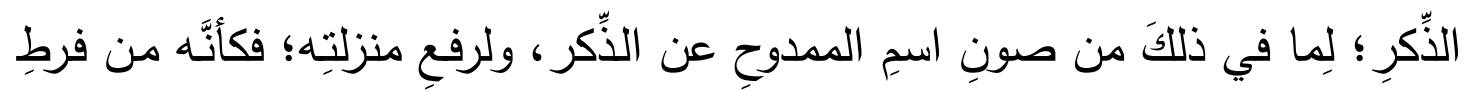

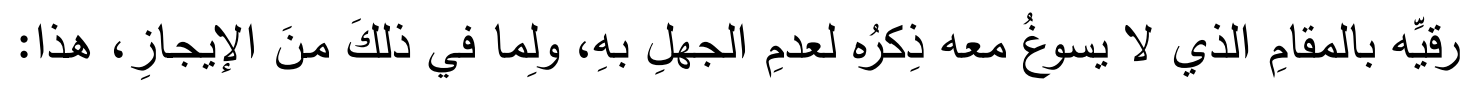

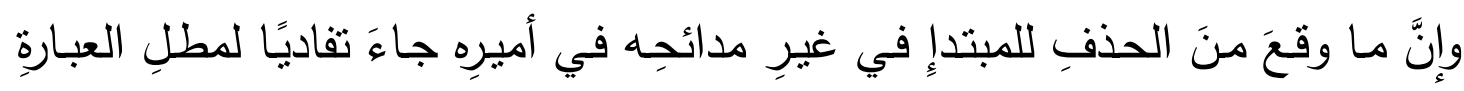

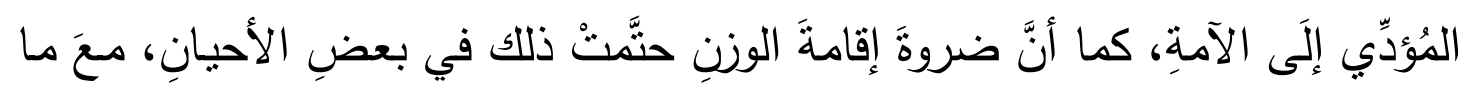

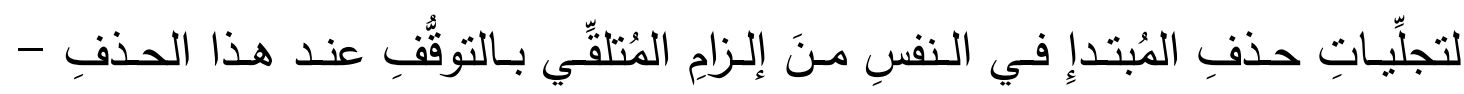

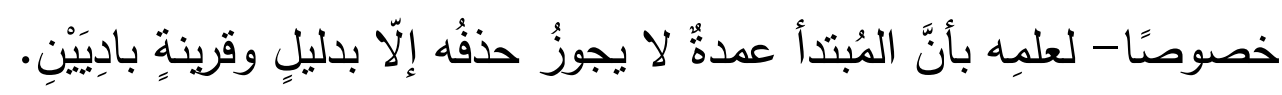

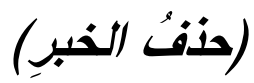

ويسعَى المُنكلًّم إلى إيصالٍ فكرتِه ومعناهُ بأقلِّ عددٍ من الألفاظِ؛ ذلك لتحقيقِ هدفِه،

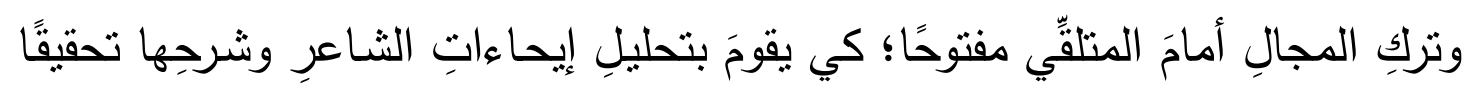

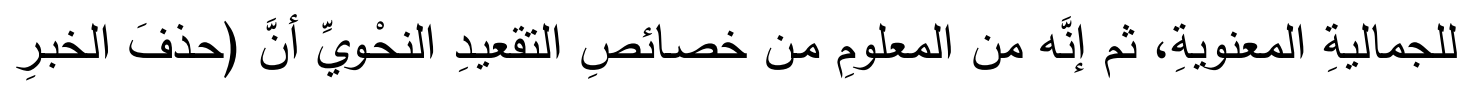

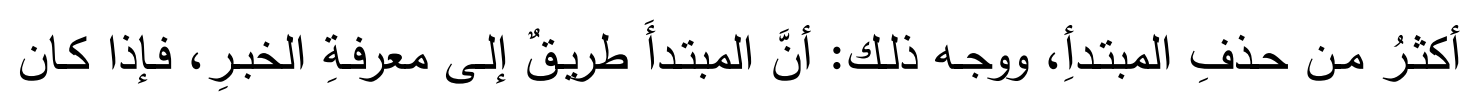

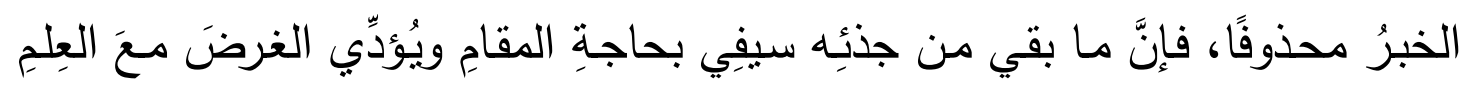

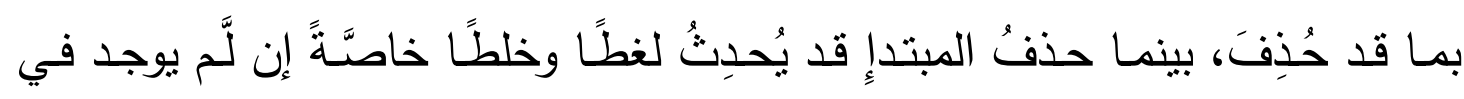

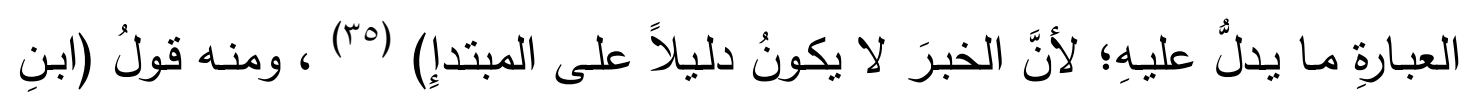


فركون): فحذف خبر لا النافيـة للجنسِ في استعمالاتِهم لاسيما إذا وقعَ في سياق

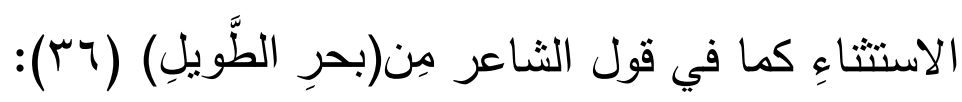

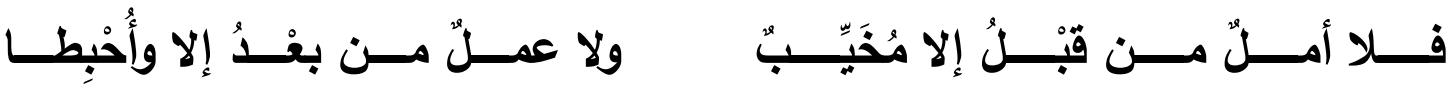

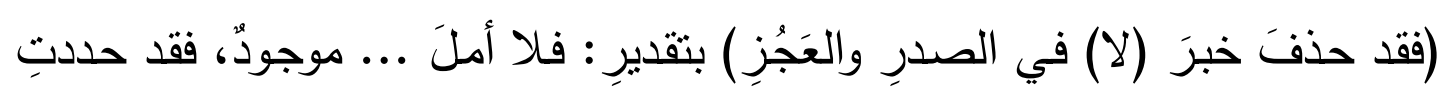

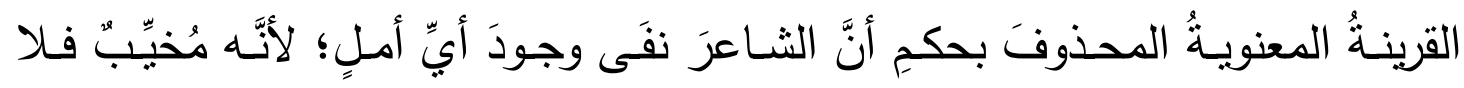

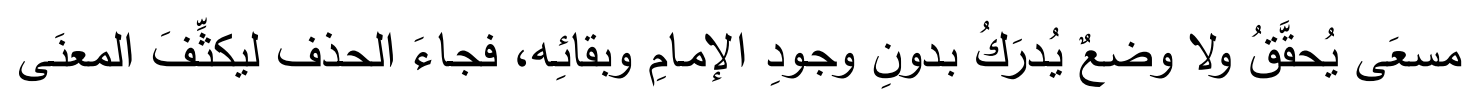
وليمنحَ البيتَ تماسكًا إيقاعيًا جميلًا.

\section{ومن الحنفِ أريضًا حنقُ خبرِ (لولا) مِن(بحرِ الطَّويلِ) (rV)}

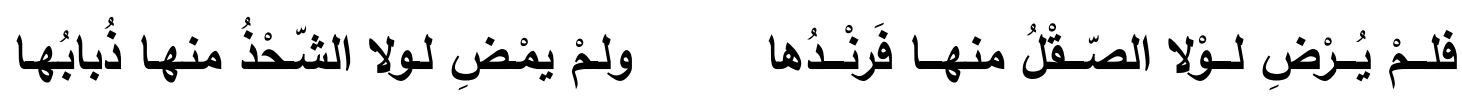

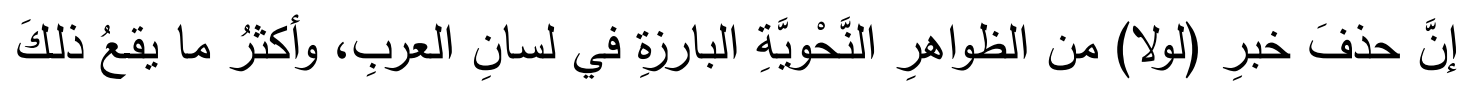

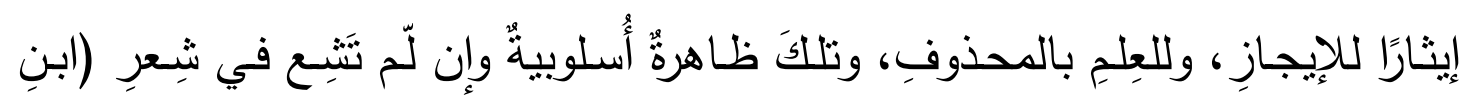

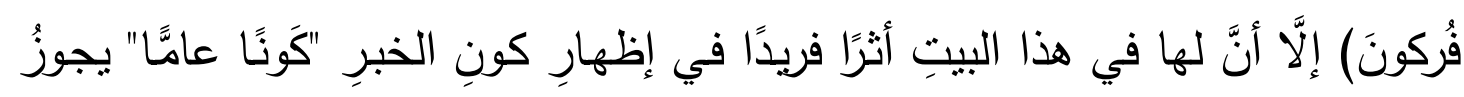

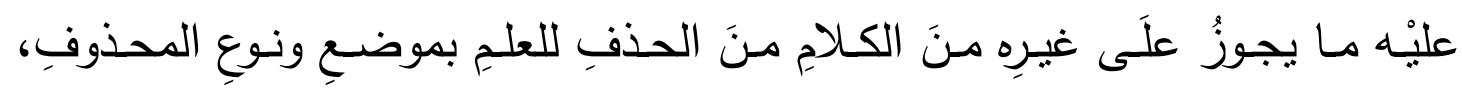

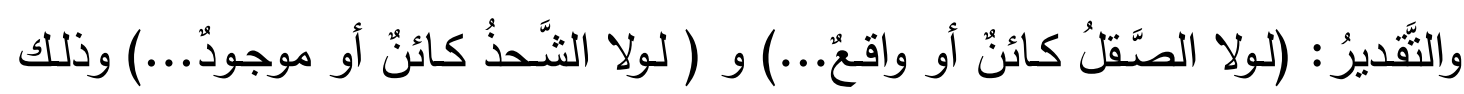

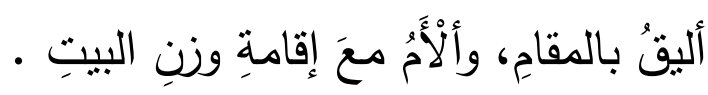

\section{(حذفَ الفاعل)}

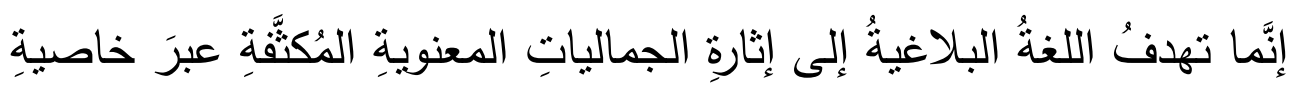

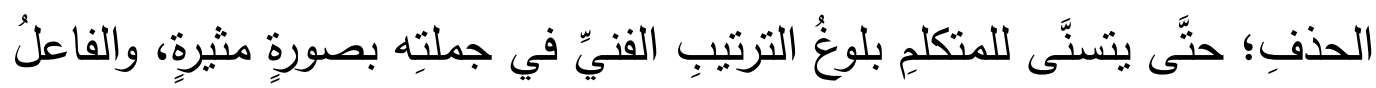

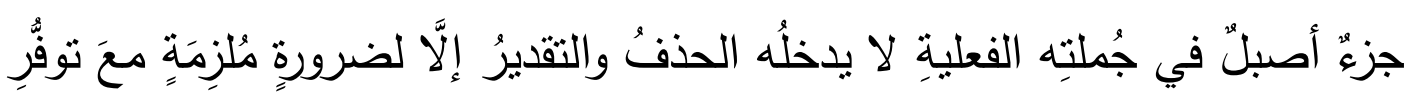




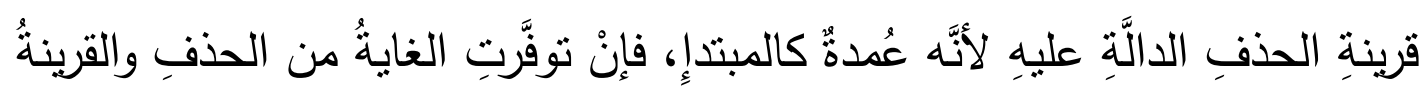

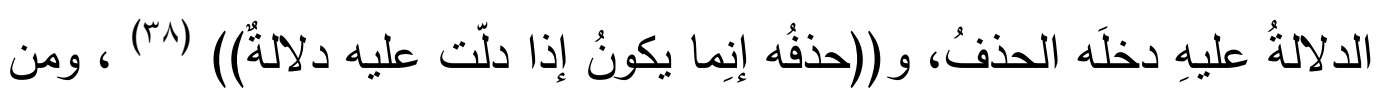

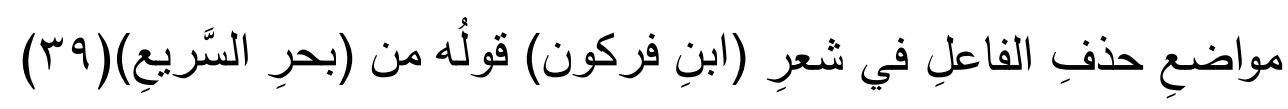

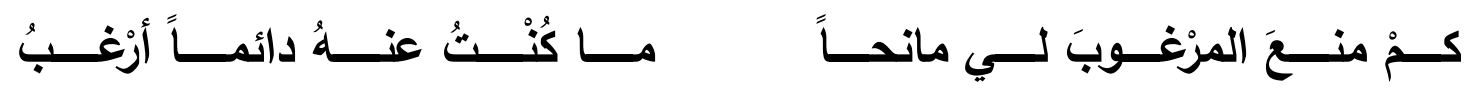

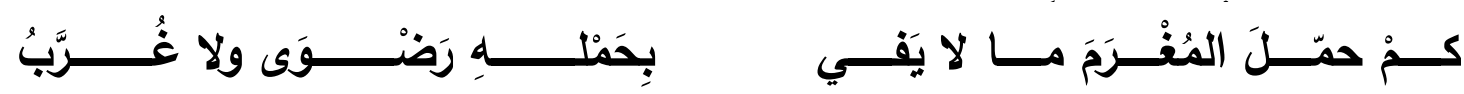
حيثُ عَمِلَ الثناعرُ عَلَى استبعادِ الفاعلِ من النصِّ لإعطائهَ قيمةً فنيةً عاليةًة

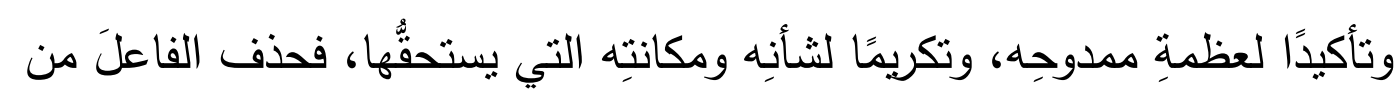

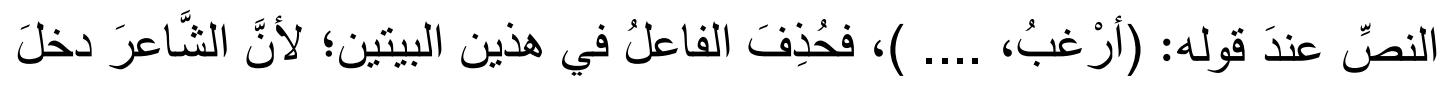

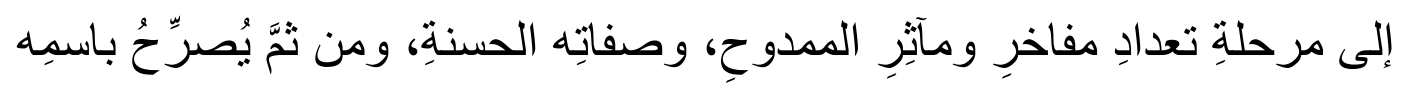
ويذكره.

\section{(حذفَ نائب الفاعلِ)}

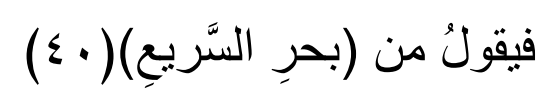

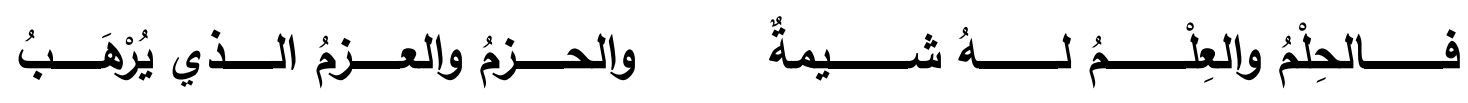

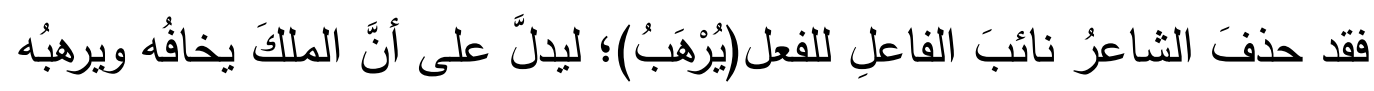

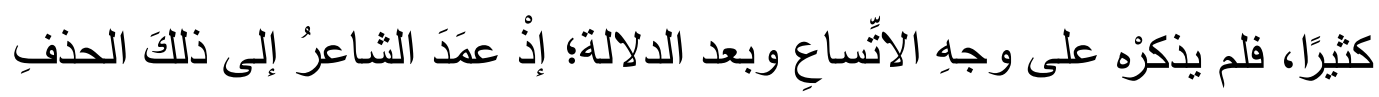

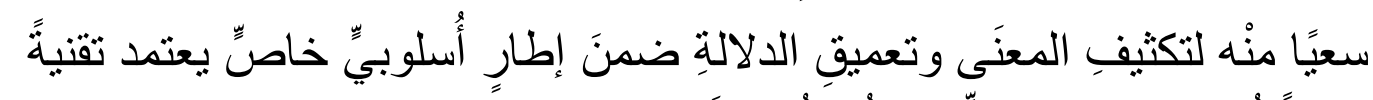

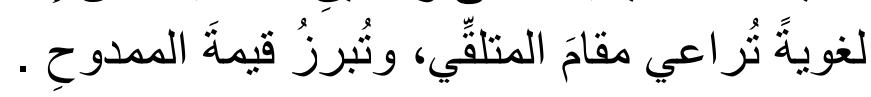

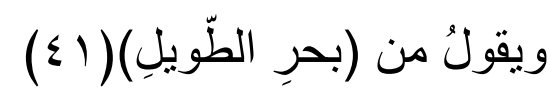

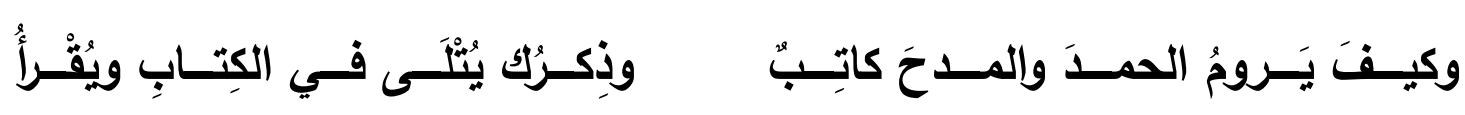

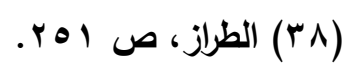

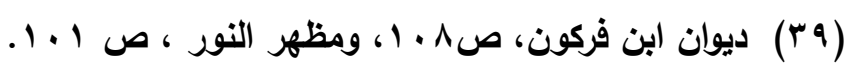

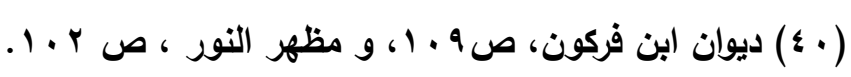

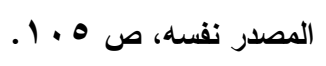




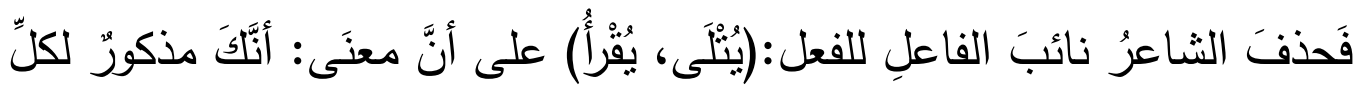

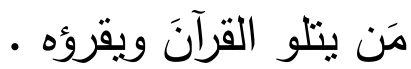

\section{(حذفنُ (لفعلِ)}

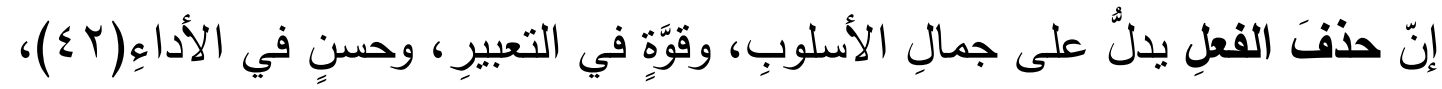
ويَردُ هذا الحذفُ في شعرِ (ابنِ فركون) بصورةٍ واسعةٍ.

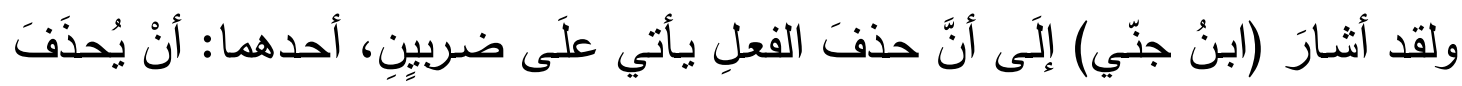

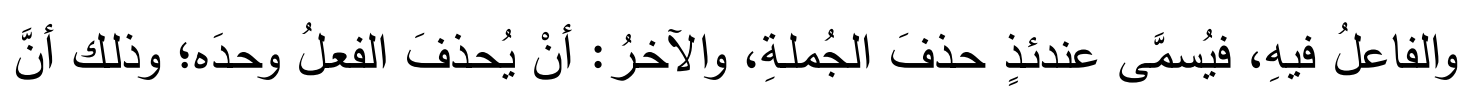

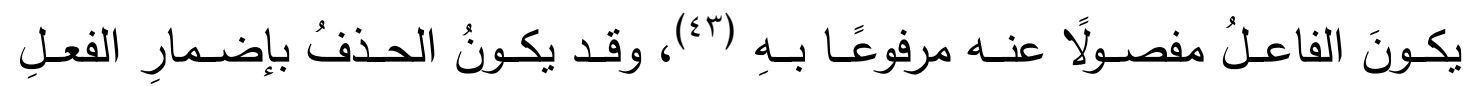

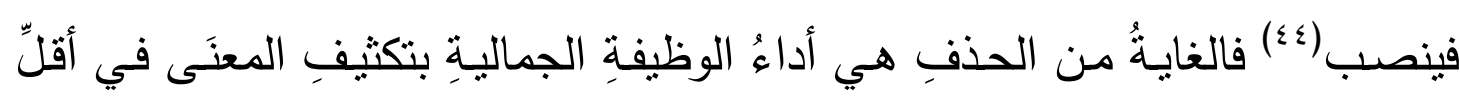

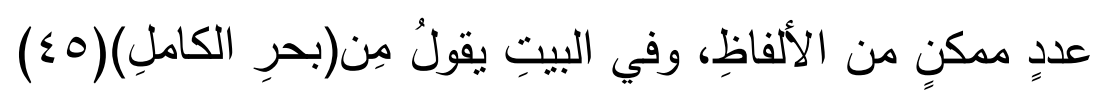

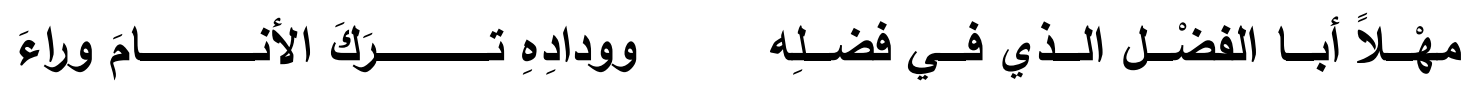

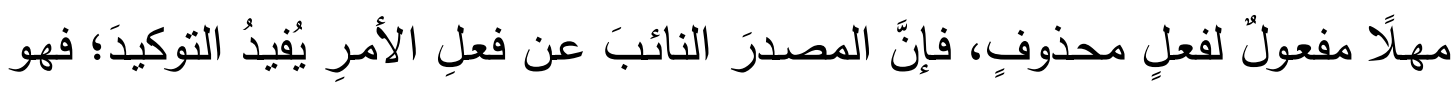

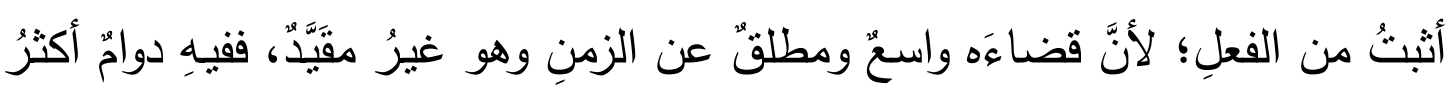

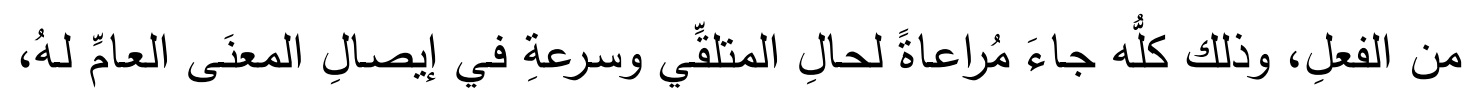

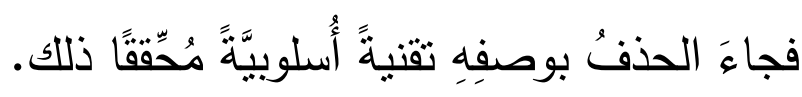

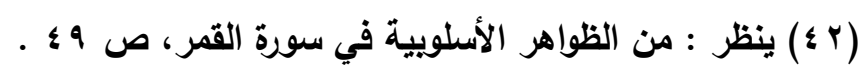

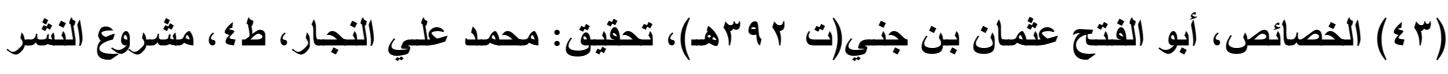

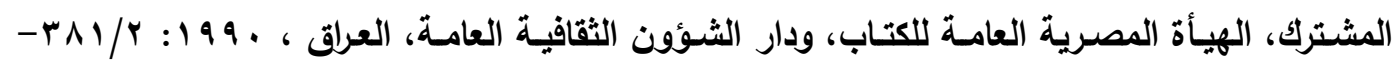




\section{المبحثُ الثَّانِي: حذفُ الفضلاتِ والمُكمِّلاتِ \\ (حذفُ المضافِ إلِيْهِ)}

وهو ضَربٌٌ منَ ضروبِ الحذفِ التي وردَت في شعرِ (ابنِ فركون)، ولهذا الضَّربِى

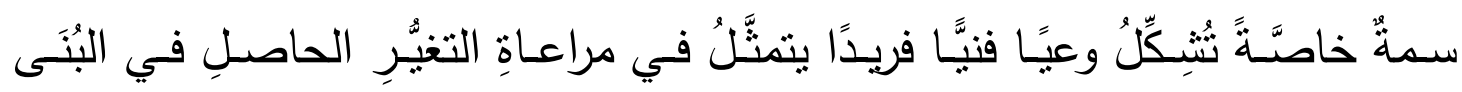

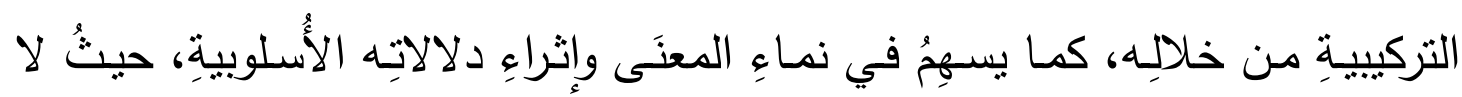
جدَوى ممَّا تجرَّدَ من الفائدةِ الدلاليةِ الجديدةِ من ذلك؛ فليسَ الحذفتُ وحدَه ما يُجسُِّ

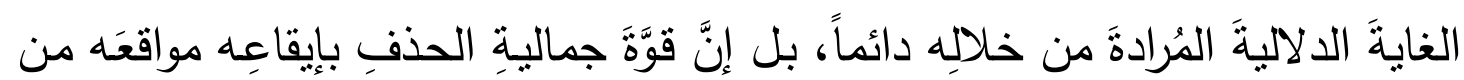

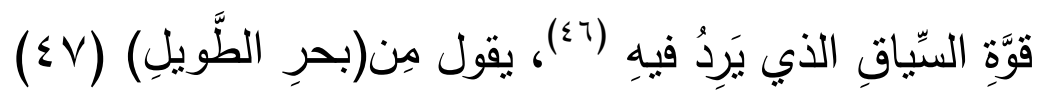

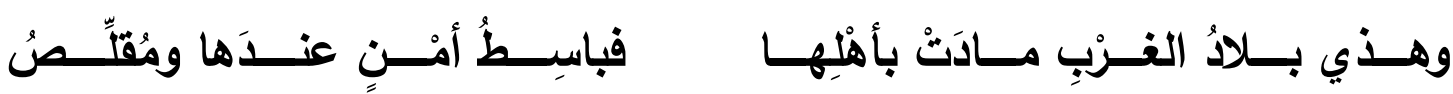

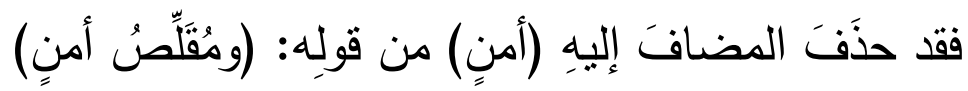

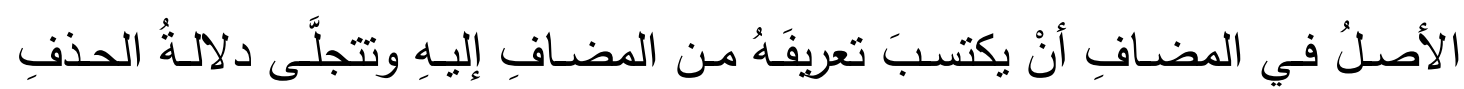

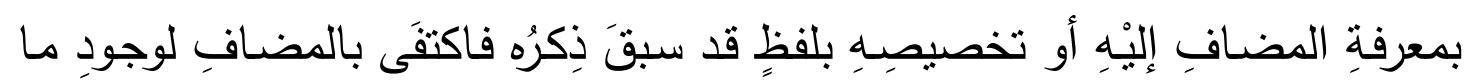

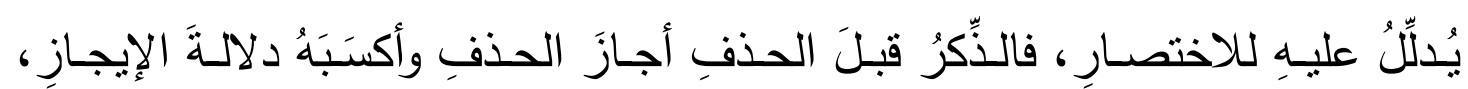
فالأمنُ هو المضافُ إليه، وقد سبق ذكرُه وهو قرينةُّ لفظيةٌ أجازتِ الحذفَ للإيجازِ والاختصارِ ؛ فلا فائدةً إذن من تكرارِه لوضوحِه ولذكرِه قبلَ الحذفِ.

\section{(حذفتُ المفعولِ بهِه)}

لقد وقفَ (عبدُ القاهرِ الجُرْجانيُّ) طويلًا أمامَ حذف المفعولِ بِهِ، متأملًَ مَواطنَ جمالِهِ لِلذَي وَجَدَة فيهِ وتحَصَّلَ له منْهُ من روافَ جماليةٍ للمعنَى، وما يحويهِ من قِيمةٍ كبرَى

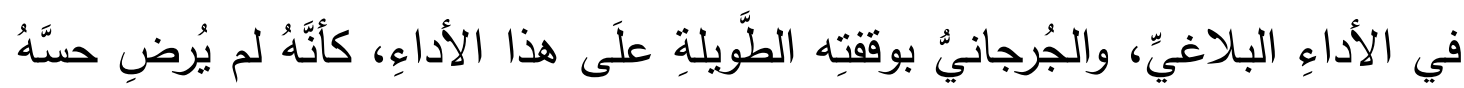


الجماليَّ عمَّا قيلَ فيهِه ممَّن سبقَه من العلماعِ في هذا الضددِ، فالمفعولُ بهه "إذا حُذِفَ خصوصًا، فإنَّ الحاجةَ إليهِ أمسُّ، وهو بِما نحنُ بصددِه أخصنٌ، واللطائفُ كأنَّها فيهِ

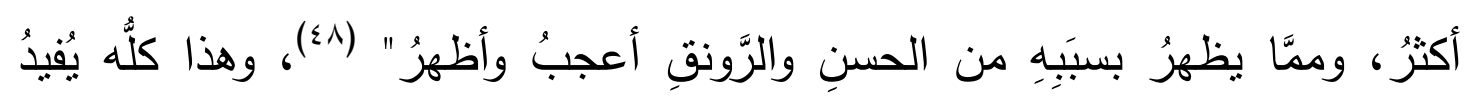
الإيجازَ الذي يُفضِي إلَى سِمات جماليةٍ تُؤَكُِّ الأداءَ الوظيفيَّ الراقِي لأسلوبٍ

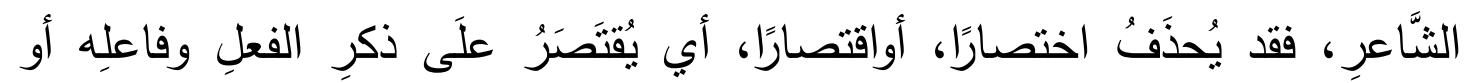

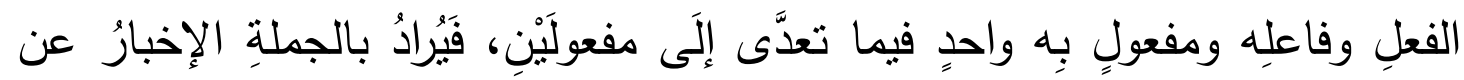

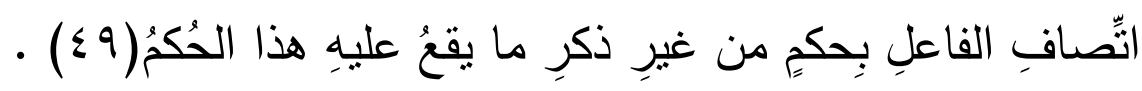

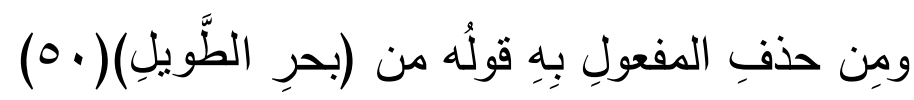

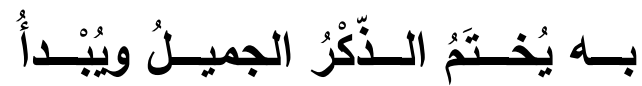

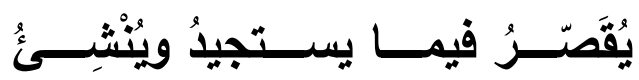

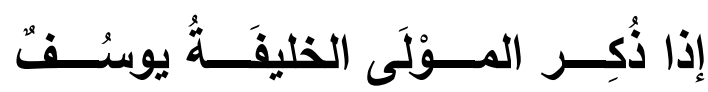

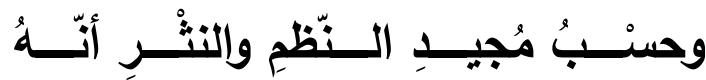

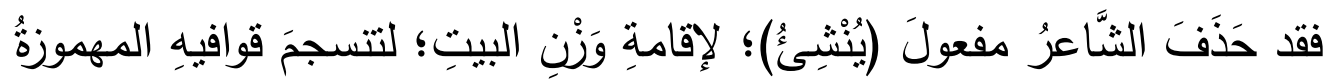

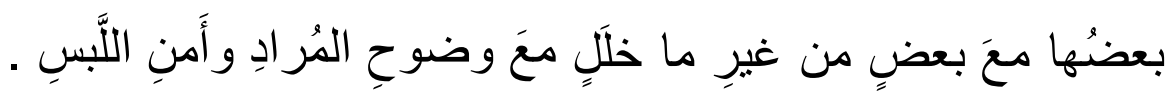
ويقولن مِن (بَحرِ الطَّويلِ)(1)

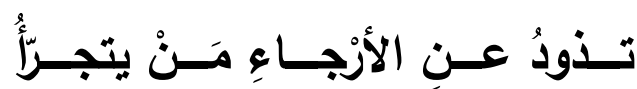

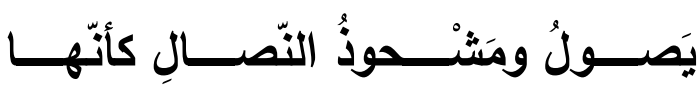

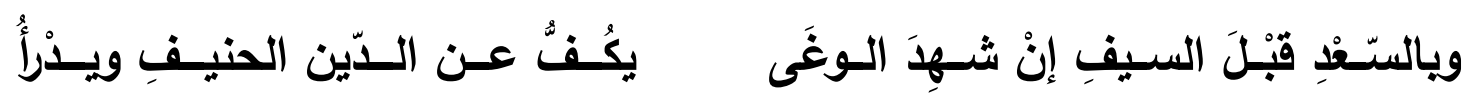

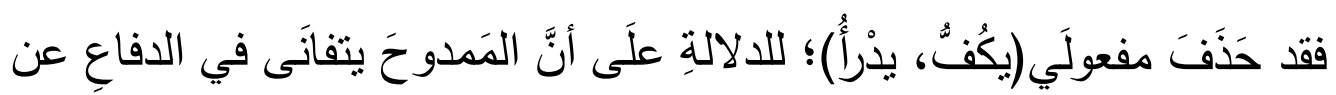

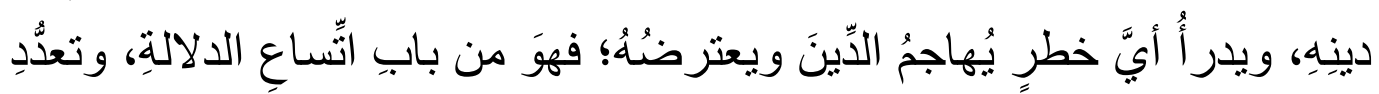

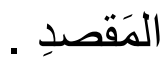

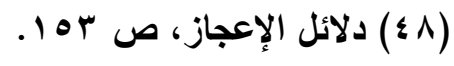

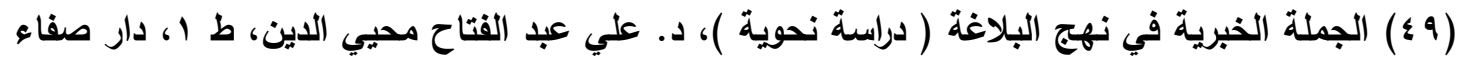

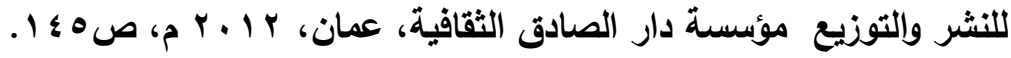

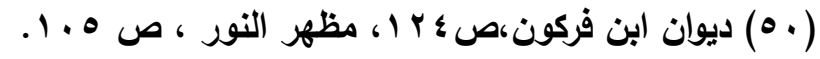

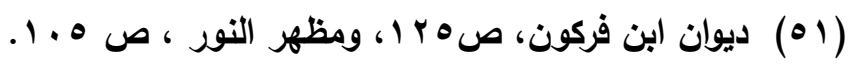




$$
\text { ويقولُ مِنْ (بحرِ السِّريع)(Or) }
$$

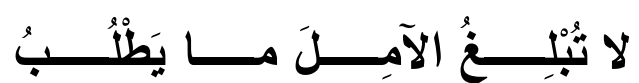

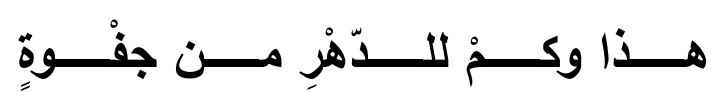

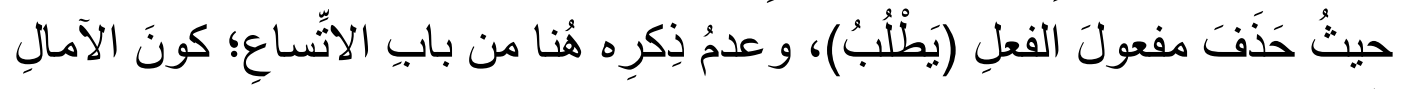

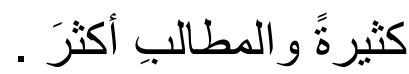

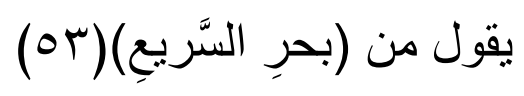

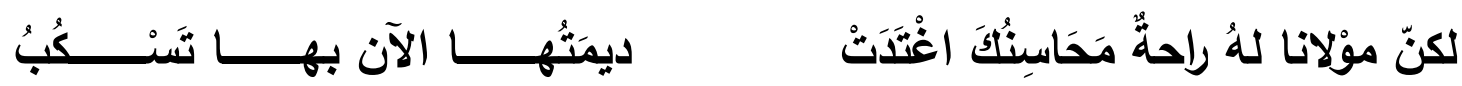

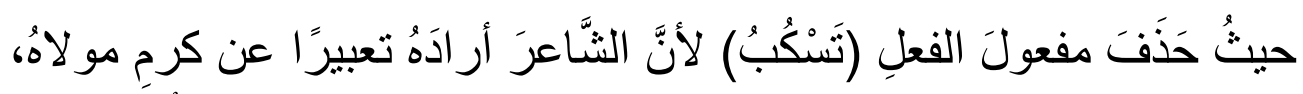

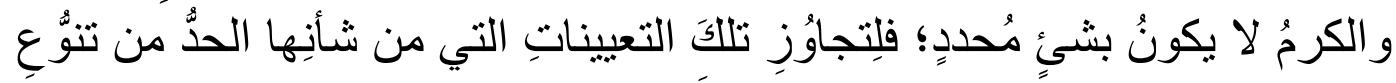

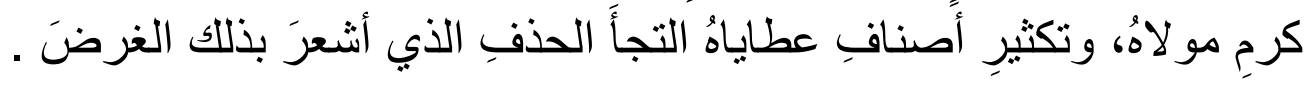
ويقولُ أيضًا مِن(بحرِ السريع)(عْم):

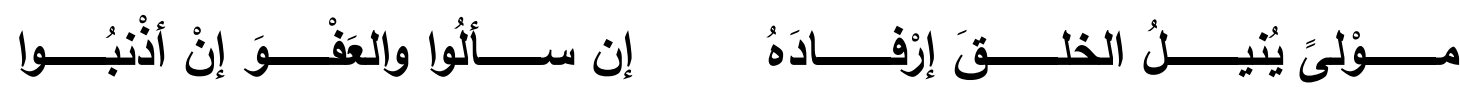

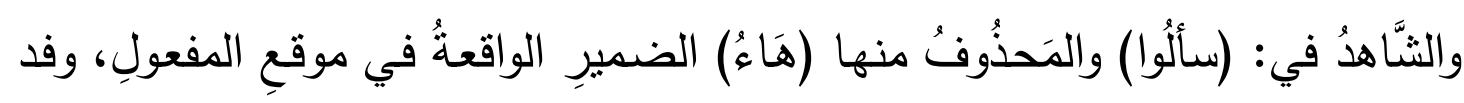

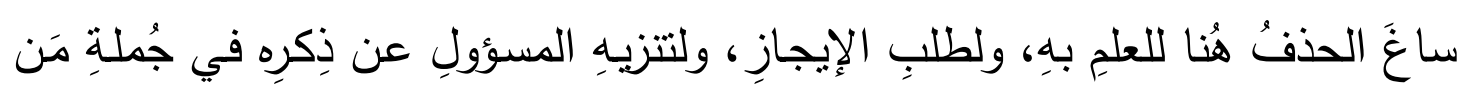

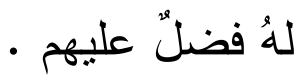

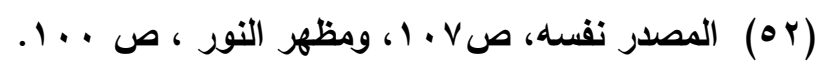

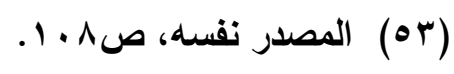

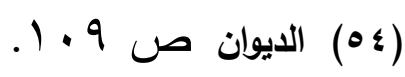




\section{(حذقَُ المَوصوفِ)}

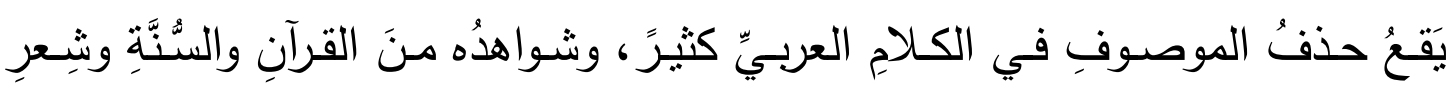

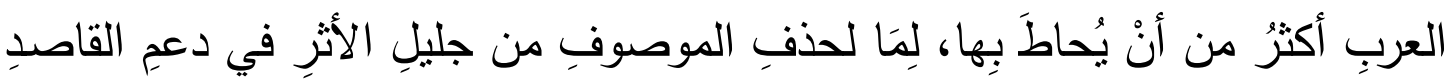

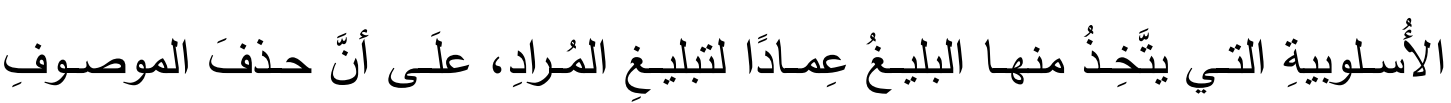

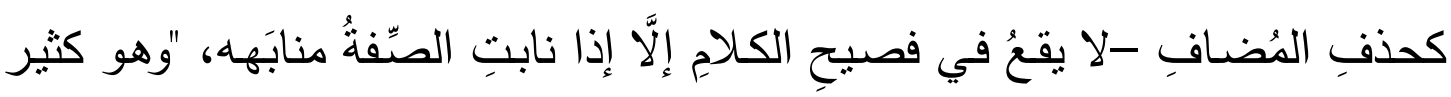
في القرآن الكريم والثشعر العربي(00)، ومِن حذفِ الموصوفِ وفي حذفِ الموصوفِ

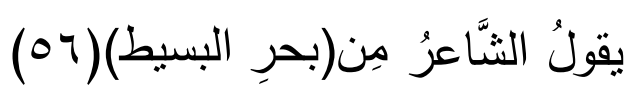

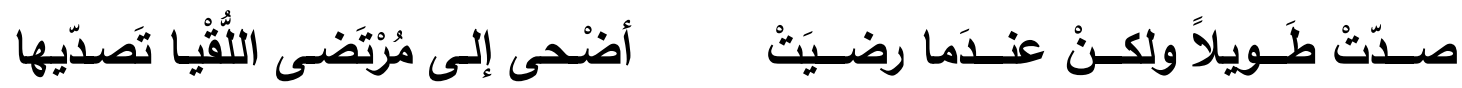

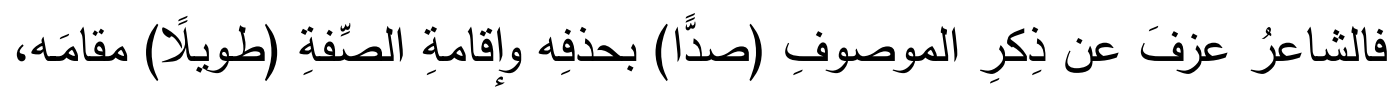

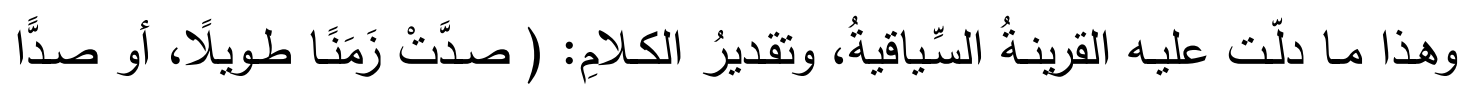

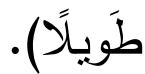
وفي حَذفب تمييزِ (كم) يقولُ مِن(بحِِ الخفيف) (OV)

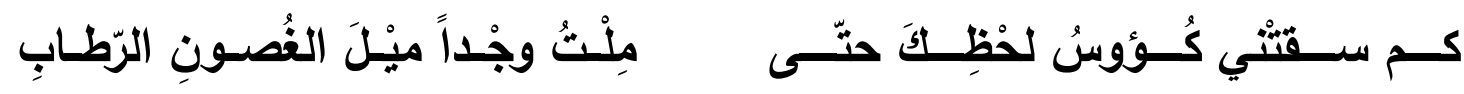
حذفُ تمييزِ (كم) والتقديرُ : "كم من كؤوسِي)

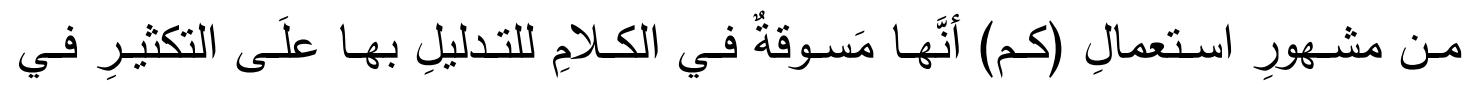

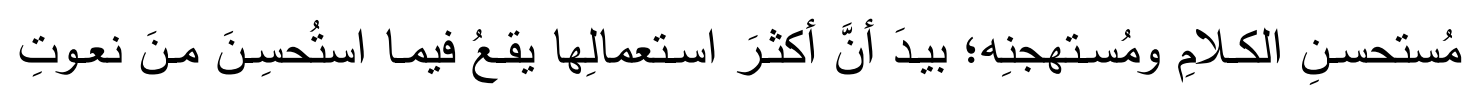

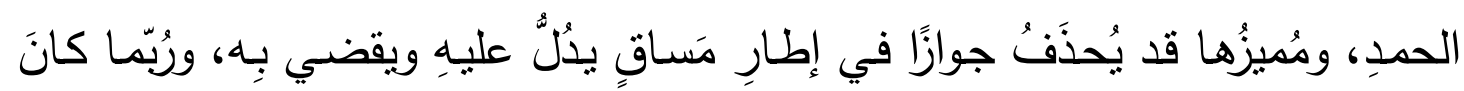
المحذوفُ مفعولاً مطلقًا وهو الـ(مرة) -أي كم مرةًً.-.

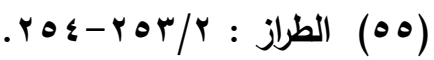

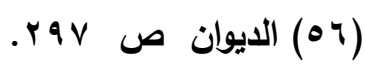

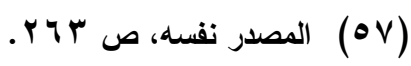




\section{المبحثُ الثََّّثُ: الحذفَُّ في الحُروفِ}

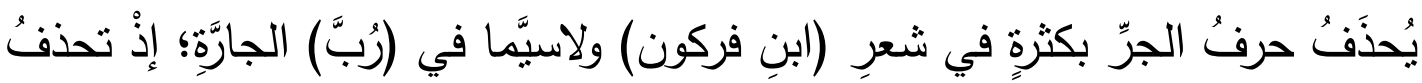

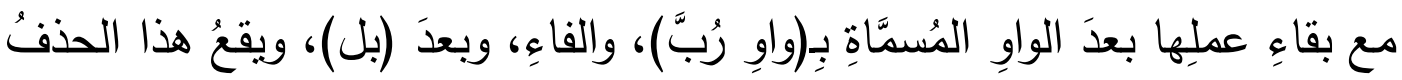

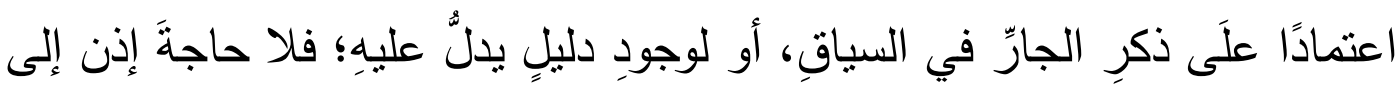

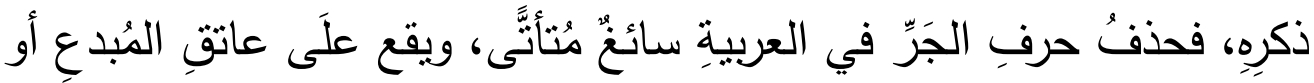

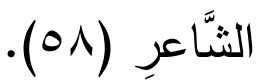

وفي غالبٍ ما ذُكِرَ من حذفٍ في حرفِ الجرٌ أفادَ الاتِّساعَ في المعنَى والثمولَ

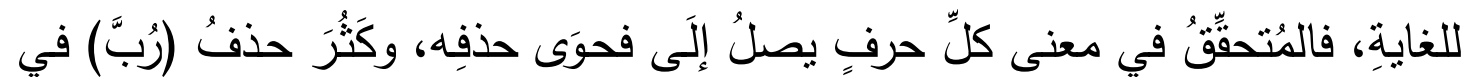

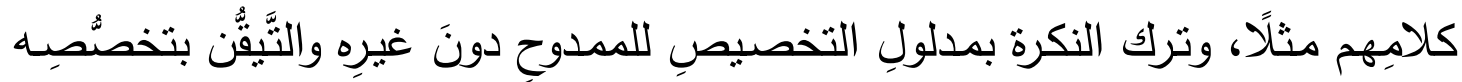

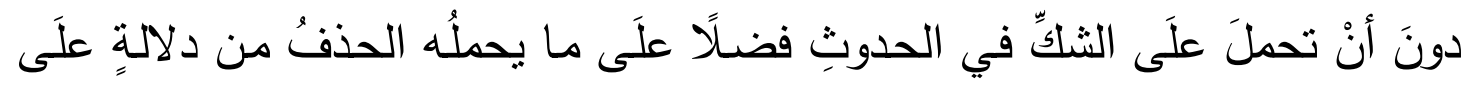

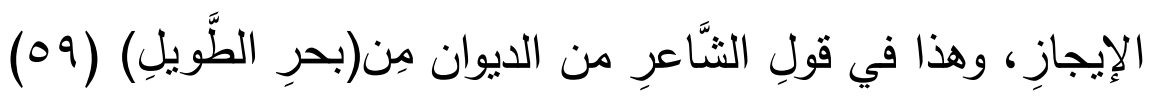

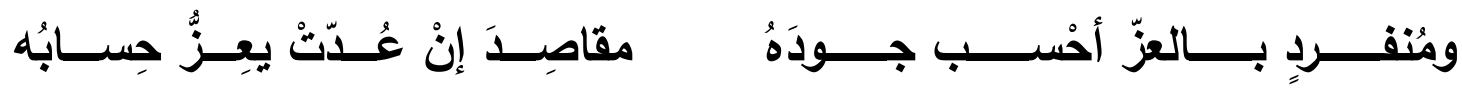

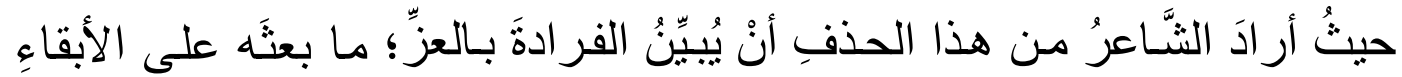
علَى الـ(الواو) دلالةً علَى بسطِ الجمالِ وتعزيزِ الخِطـابٍ الحواريِّ، فالتقدير : (ورُبَّ

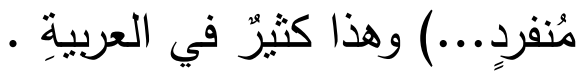

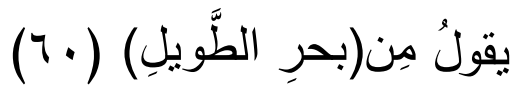

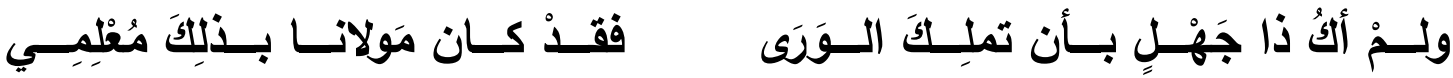

(1ه) ظاهرة الحذف في الدرس اللغوي ، طاهر سليمان حمودة ، د ـ ط ، الدار الجامعية للطباعة والنشر

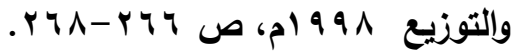

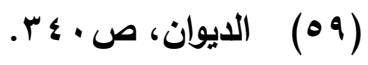
المصدر نفسه، ص بَ آ. 
وقد يحذف النون في لم أك لتخفيف الحدث تَقليل الزمن أو للاختصار؛ لأن المقام يقتضي ذلك أو لسرعة الوصول إلى الغرض الرئيس من الكلام.

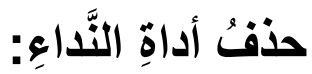

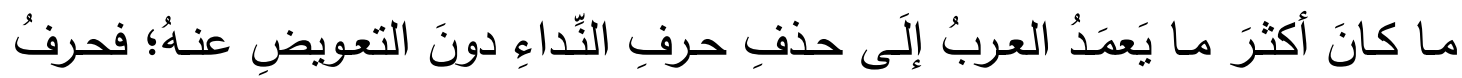

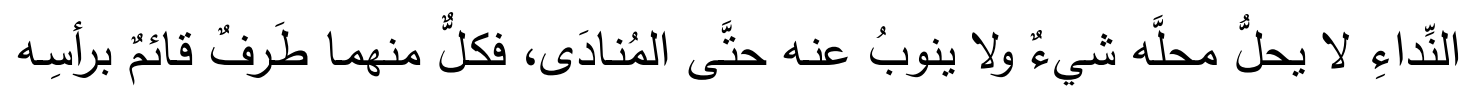

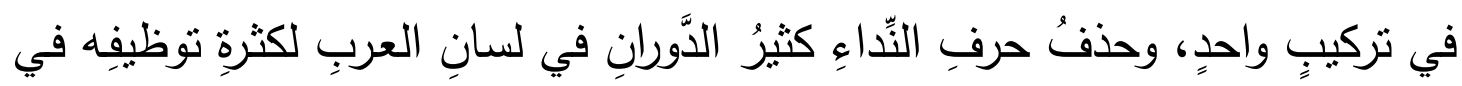

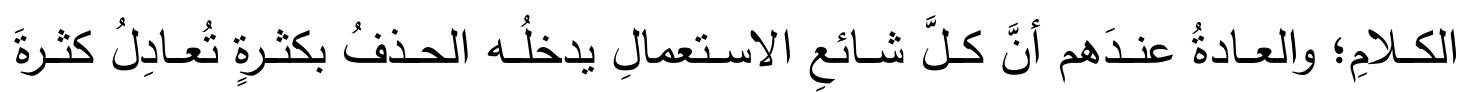

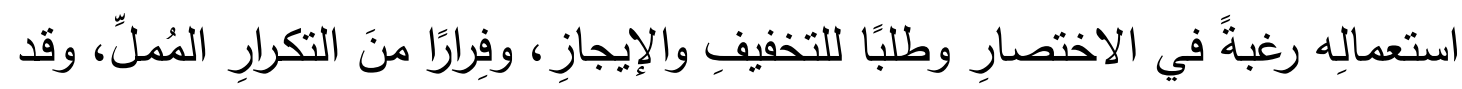

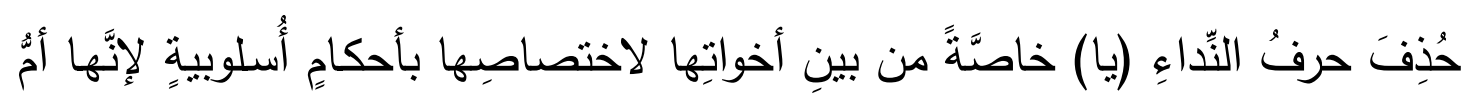

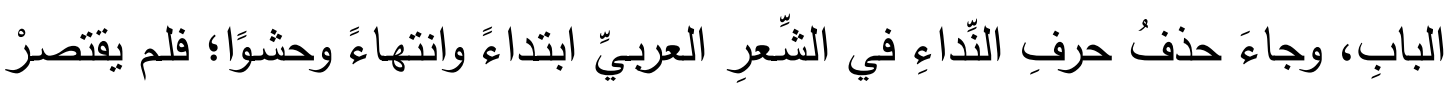

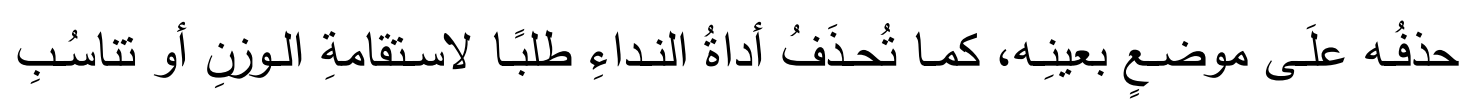

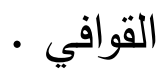

\section{ومِن حذف حرف النداءِ قولُ شاعرِنا مِن(بحرِ البسيط) (1)}

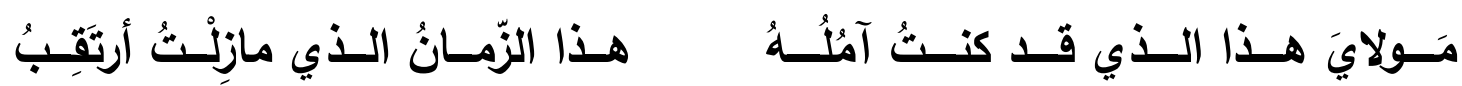

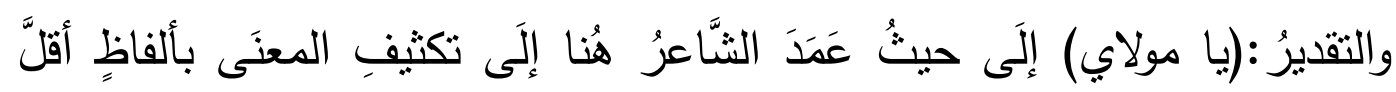

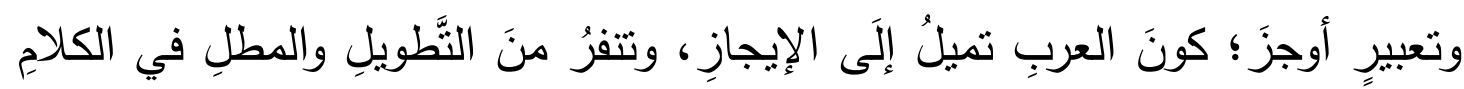

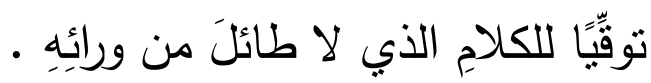

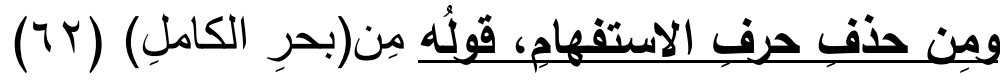

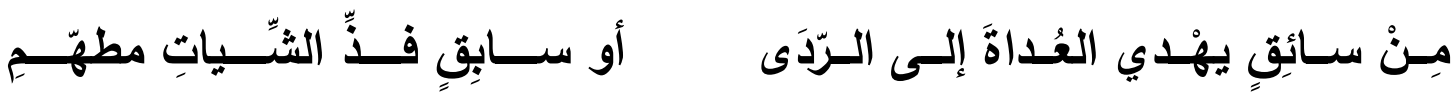

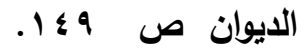

المصدر نفسه، ص q Y Y. 


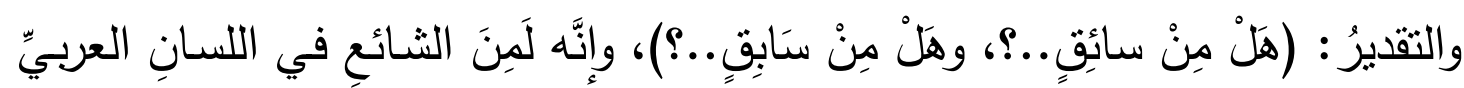

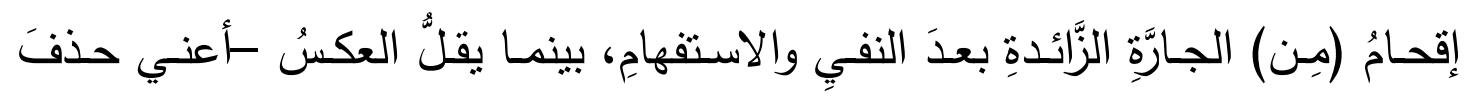

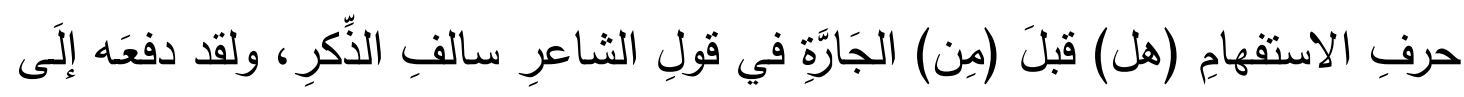

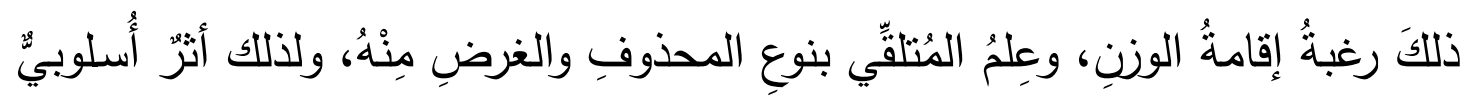

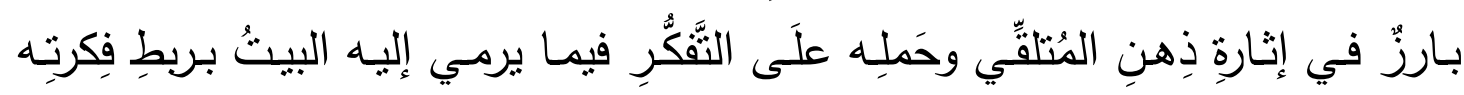

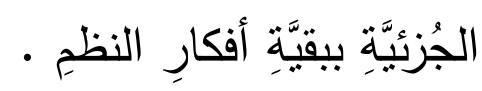

\section{المبحثُ الرَّابع: الحذفَ في التَّركيب الثَّرطيّي:}

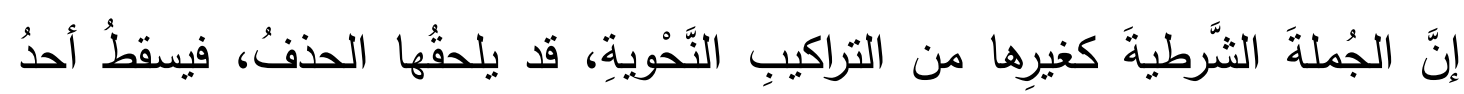

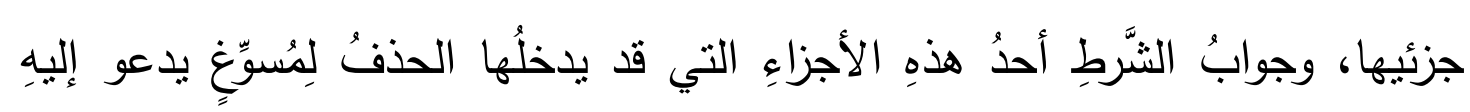

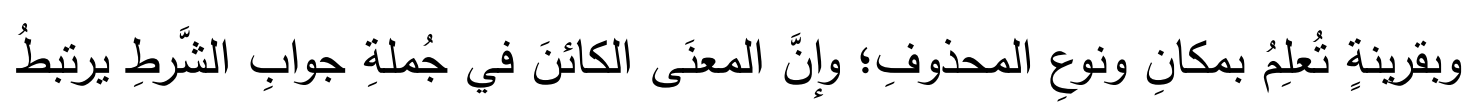

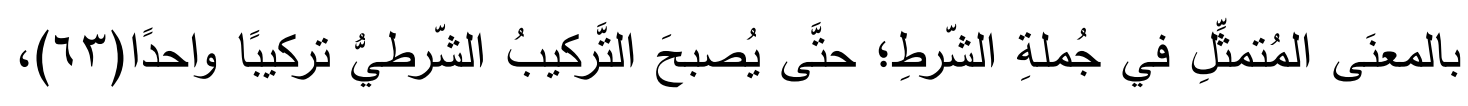

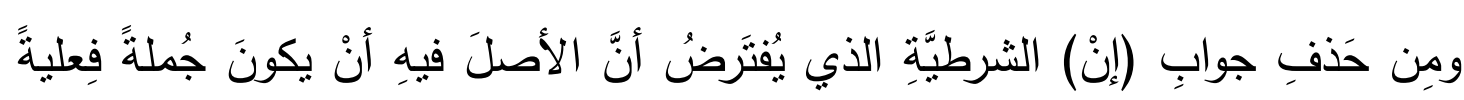

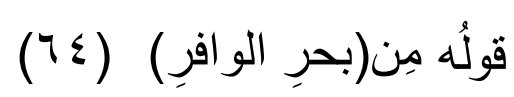

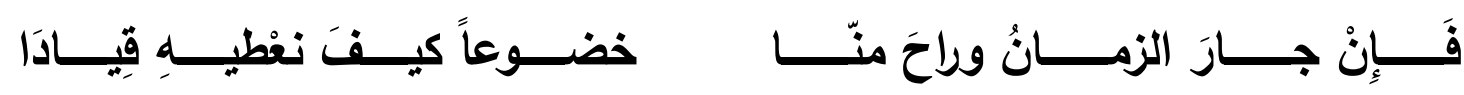

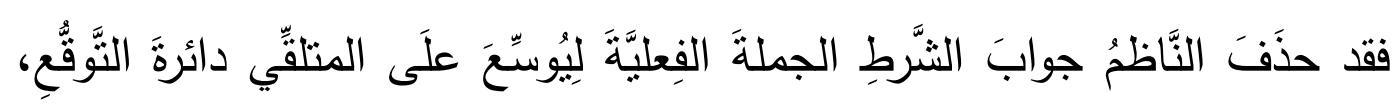

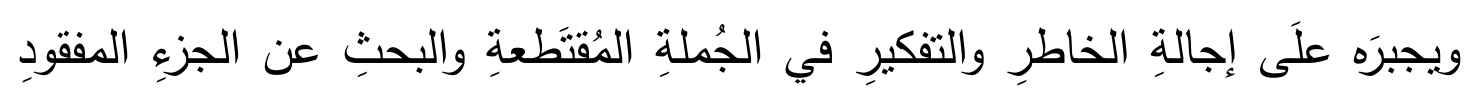

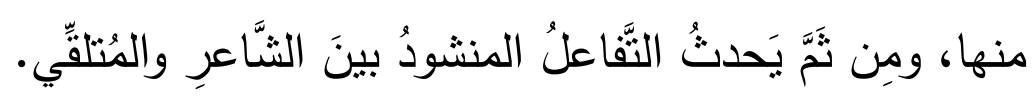

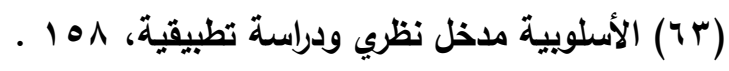

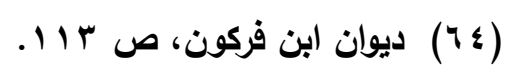




\section{(حذفُ الجُملةِة الفِعليةِ)}

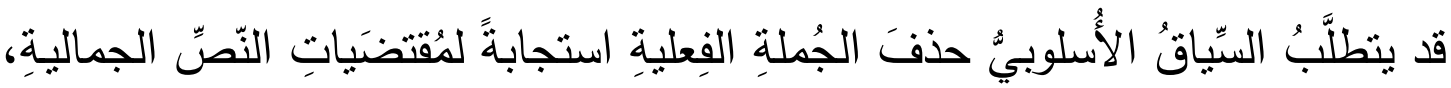

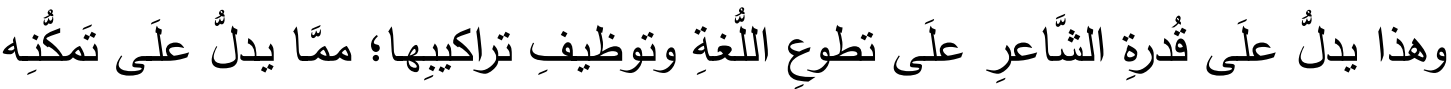

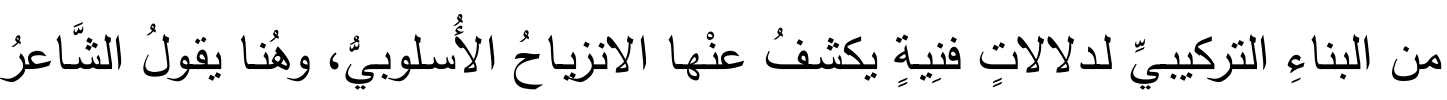
مِن(بحرِ الكاملِ) (70)

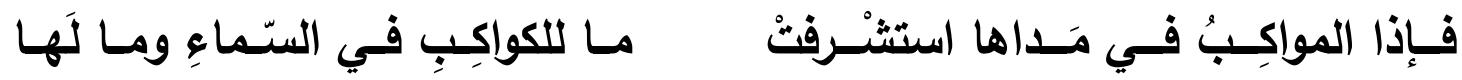

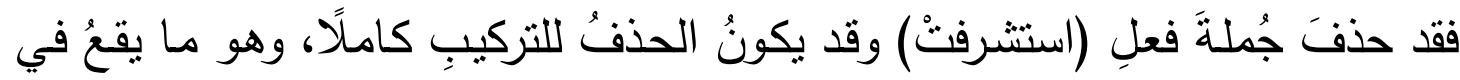

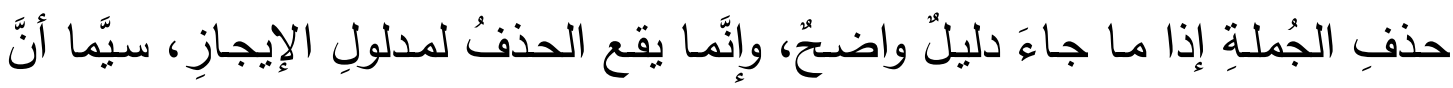

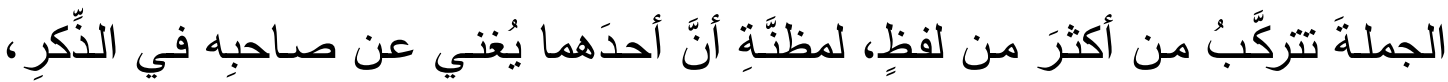
وممَّا جاءَ علَى ذللك قولُ الثنَّاعرِ :

وخلاصةُ القولِ: أنَّ الحذفَ لََى (ابنِ فركون) من السِّاتِ الأُسلوبيةِ المائزةٍ

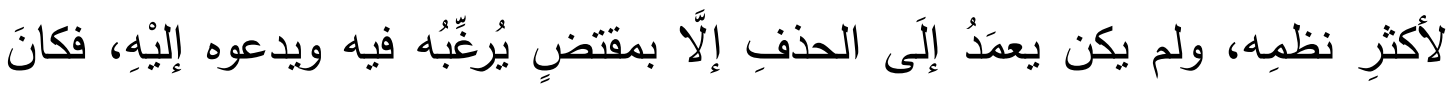

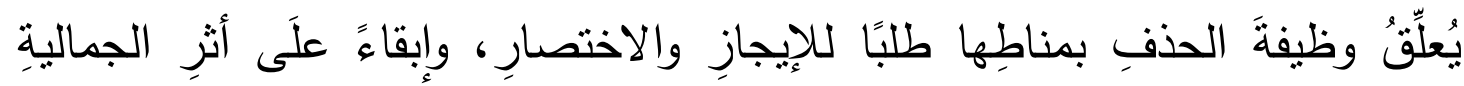

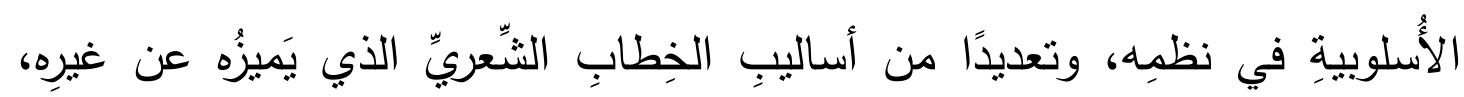
وفرارًا من مزالقِ الإطالةِ غيرِ المرغوبِة في النَّظمِ، إلَّى جانبِ استثارِه الحذفَ في

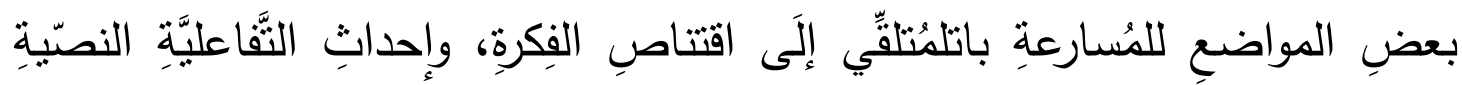

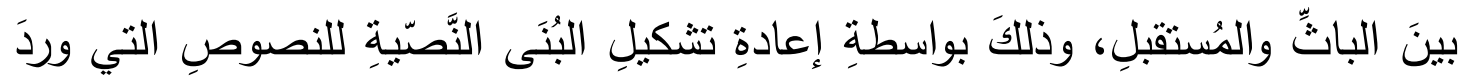

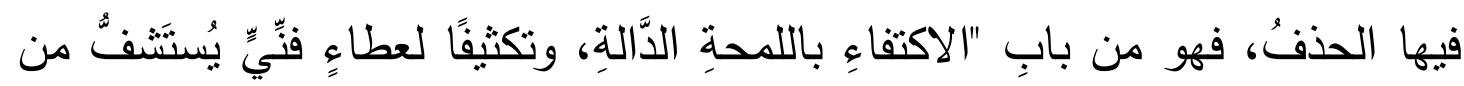

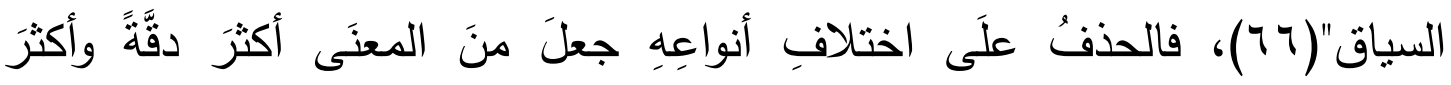

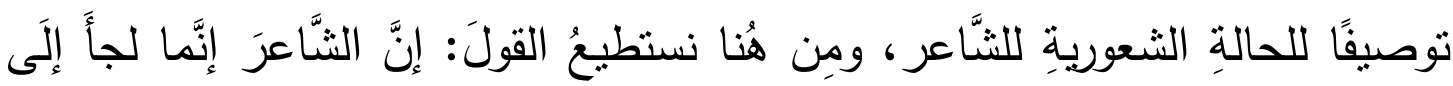

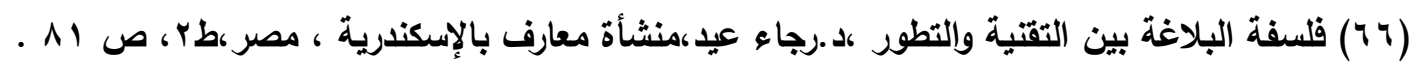




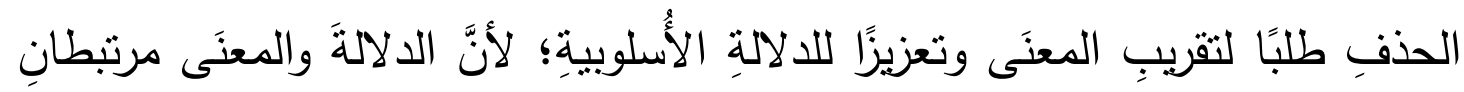

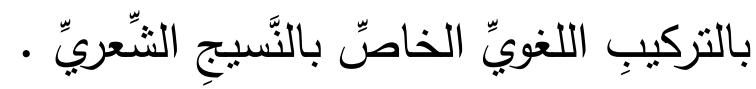




\section{الخاتمة}

هذا، وبعدَ مُطالعةٍ لأنواع الذِّكرِ والحذفِ فيما سلفَ مِن ذللكَ البحثِ؛ فقد حقَّقَ الحذفُ سمةً أُسلوبيةً واضحةً في شعرِ ابن فركون الغرناطي؛ إذ أسهرَ في تحقيقِ الغايةِ الجماليةِ، ويقعُ تأويلُ المحذوفِ علَى عاتقِ المُتنلِّي إلَّى جانبِ الانتباهِ للالالاتِ

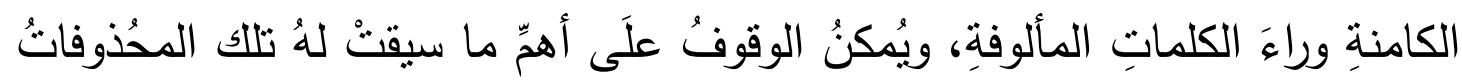

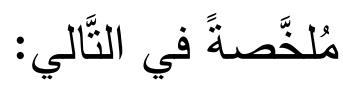
أ- حذفُ فضولِ القولِ طلبًا للإِيجازِ والاختصـارِ

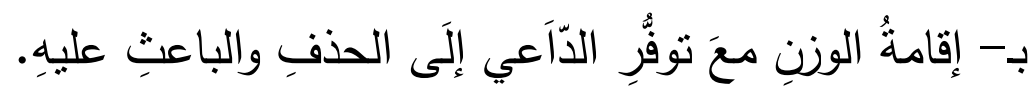

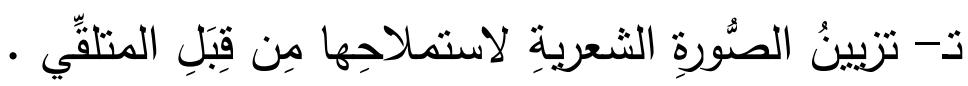
ج- حتثُ المُتلقِّي علَى إعمالِ الخاطرِ، وإمعان الفِكِر.

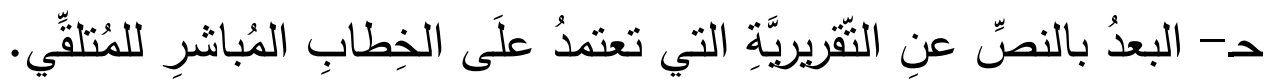

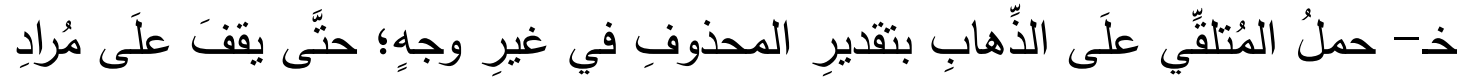

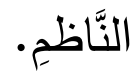

وذلكم مِن أظهرِ ما امتازَ بهِ (الحذفُ) في مُختلفِ أنواعِه عندَ (ابنِ فُركون) من

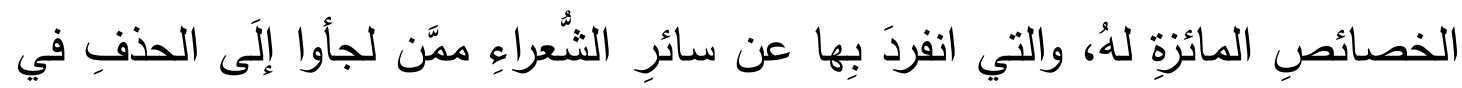

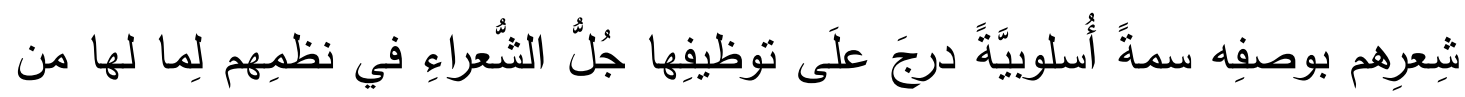
بالغِ الأثرِ في تكثيفِ المعاني بأقلِّ الألفاظِ، وإنفاذِ رغبةِ الثَّاعرِ في النَّعيةِة، أو

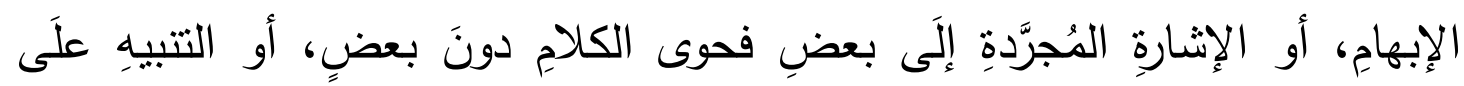
أهميَّةِ المذكورِ في مُقابلِ المدذوفِ، ولتمكينِ المعاني المحذوفةِة في نفسِ المُتلقِي بمحاولةِ استدعائهِا بنفسِه. 
ثُبتُ المصادرِ والمراجع

أولا : المصادر

() الإحاطة في أخبار غرناطة" لسان الدين بن الخطيب، تحقيق: محمد عبد

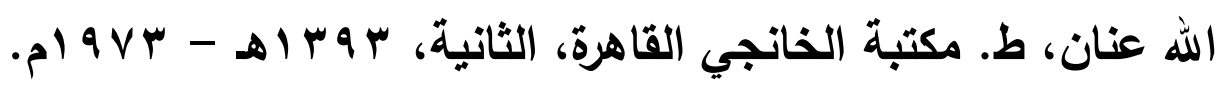

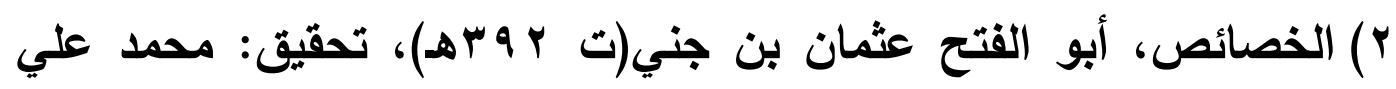

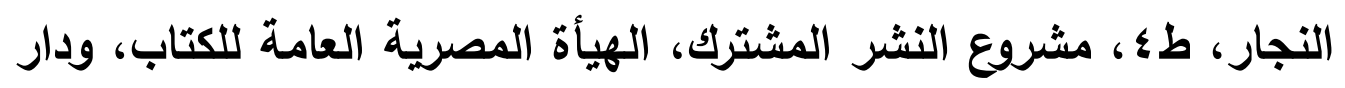

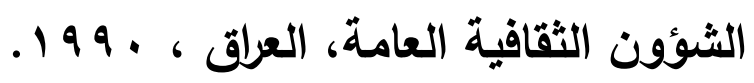
r) خطرة الطيف، رحلات في المغرب والأندلس، لسان الدين بن الخطيب،

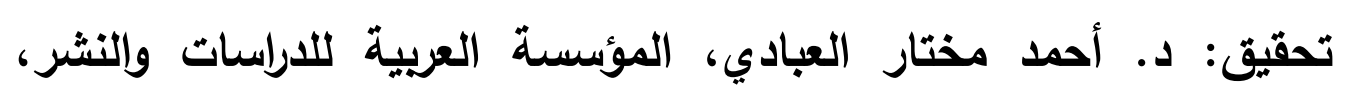

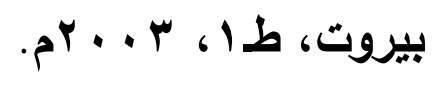

؛) دلائل الإعجاز، الشيخ الإمام أبو بكر عبد القاهر بن عبد الرحمن بن محمد

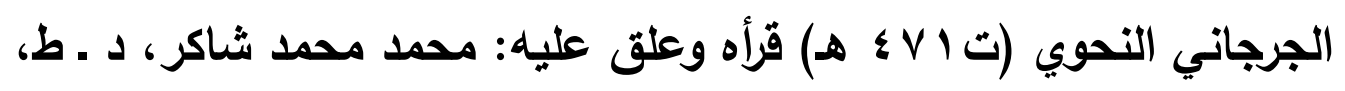

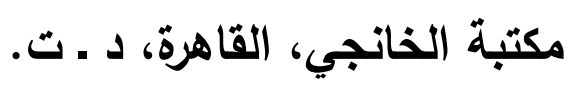

•) ديوان "ابن فركون" تقديم وتعليق محمد بن شريفة، ط. أكاديمية المملكة

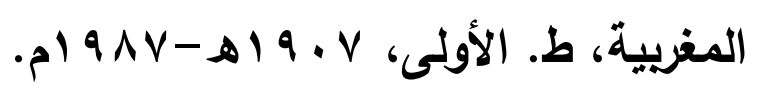

4) الروض المعطار في خبر الأقطار، لمحمد عبدالمنعم الحِمْيري، تحقيق:

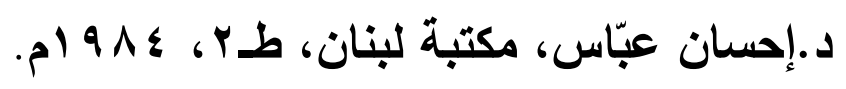

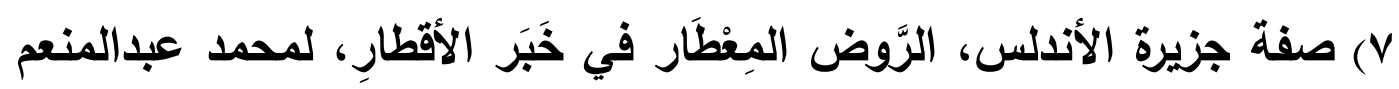

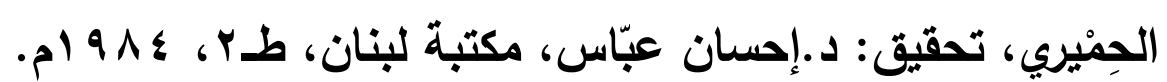

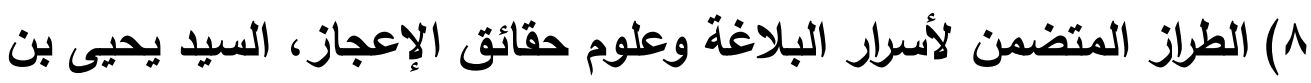

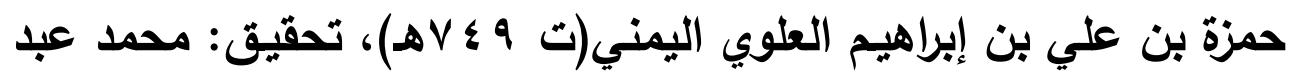

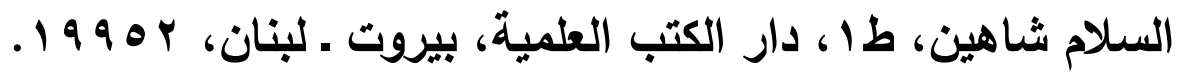

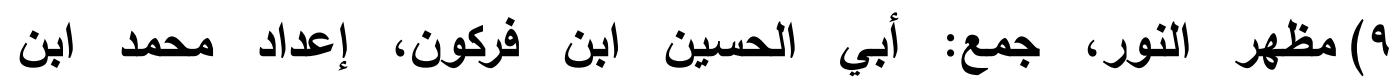

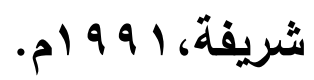


• 1 ) معجم البلان، للشيخ الإمام شهاب الدين أبي عبدالله ياقوت بن عبدالله الحموي الرومي البغدادي، دار صادر، بيروت، لو 9 ام.

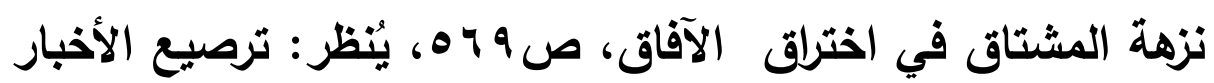

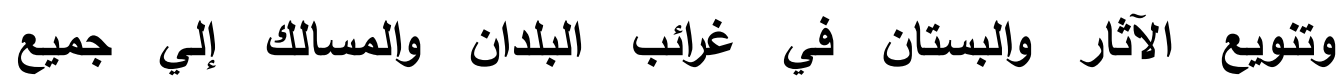
الممالك،لأحمد بن عمر بن أنس العذري المعروف بابن الدلائي، تحقيق: د. د. عبدالعزيز الأهواني، منشورات معهد الدراسات الإسلامية في مدريد(د.ت).

\section{ثانيًا: المراجع العلمية}

الأسلويية مدخل نظري ودراسة تطبيقية ، دـ ـ فتح الله أحمد سليمان

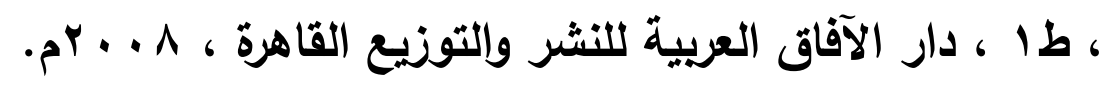

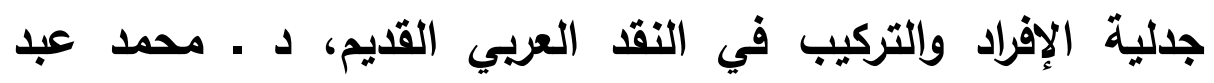

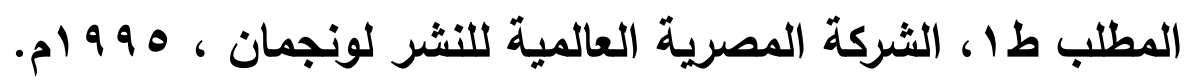

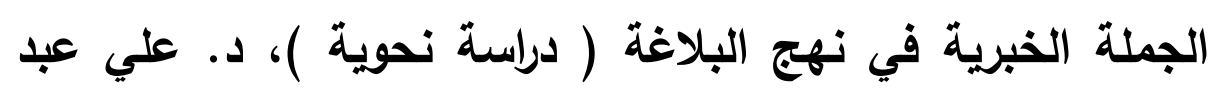

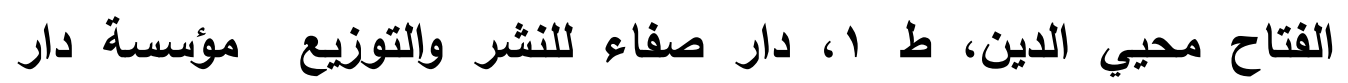

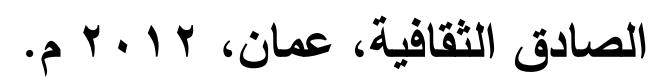

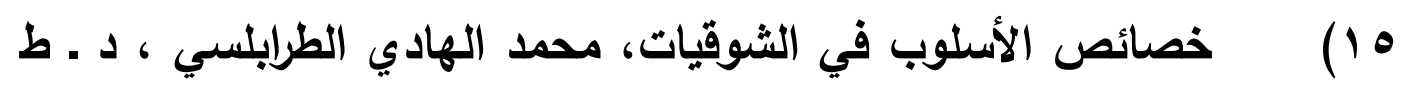

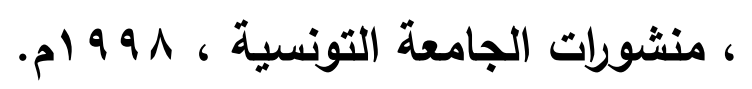

ظاهرة الحذف في الارس اللغوي ، طاهر سليمان حمودة ، د ـ ط ، الدار الجامعية للطباعة والنشر والتوزيع ه9 99 ام.

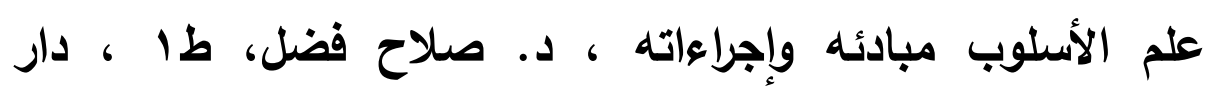

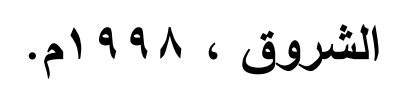

فلسفة البلاغة بين التقتية والتطور ،دورجاء عيد،منشأة معارف

$$
\text { بالإسكندرية ، مصر، طץ. }
$$

لسانيات النص ( مدخل إلى انسجام الخطاب ) ، محمد خطابي ،

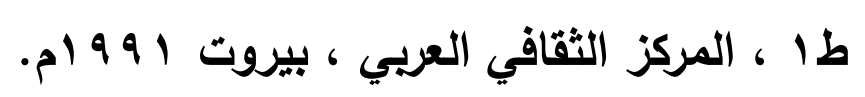




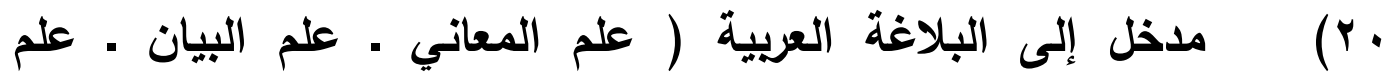

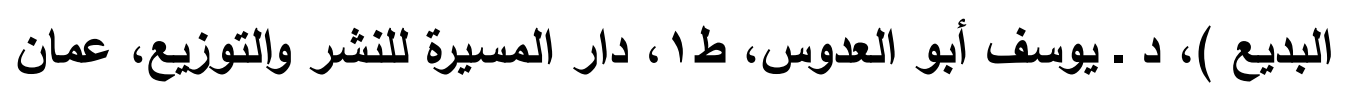

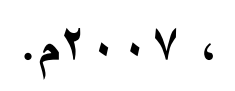

معجم الحضارة الأندلسية، د. يوسف عيد، و د. شكري فرحات، طا،

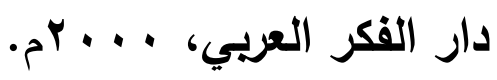

$$
\begin{aligned}
& \text { ثالثًا: الكتب المترجمة }
\end{aligned}
$$

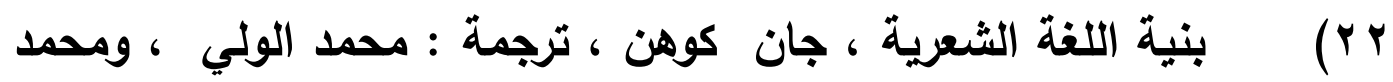

$$
\begin{aligned}
& \text { العمري ، الأر البيضاء ، المغرب ، دار تويقال ، 4919 ام. } \\
& \text { رابعًا: الرسائل العلمية }
\end{aligned}
$$

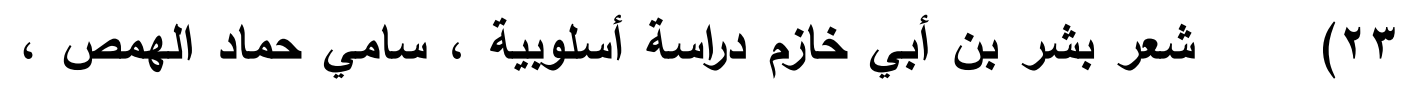

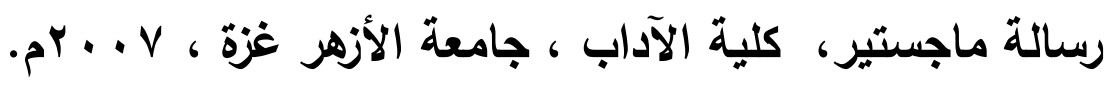

$$
\begin{aligned}
& \text { خامسًا: المجلات والدوريات }
\end{aligned}
$$

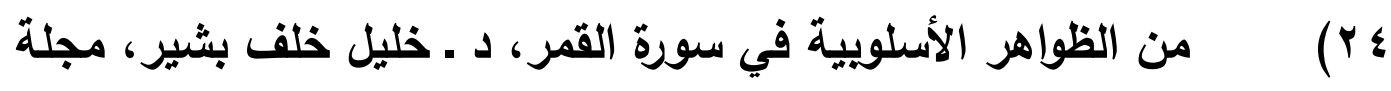

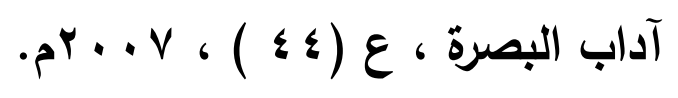

This, and after reviewing the types of mention and omission in the

aforementioned research in that research, it is possible to find out the most important things that these deletions have made for him, summarized in the following

The omissions achieved an obvious stylistic theme in the poetry of Ibn Farkoon.These stylistic themes appears greatly in the poet's experience as he is the most one who omitted the name of the praised one as he is refered in the meaning and his many good qualities 